PNL-6818

UC-423

$10 B$

First Annual Progress Report

\title{
BEATRIX-II Program
}

January 1988 to December 1988

ANNEX-III to IEA Implementing Agreement

for a Programme of Research and

Development on Radiation Damage

in Fusion Materials

G. W. Hollenberg

March 1989

Prepared for the U.S. Department of Energy under Contract DE-AC06-76RLO 1830

Pacific Northwest Laboratory

Operated for the U.S. Department of Energy

by Battelle Memorial Institute 


\title{
DISCLAIMER
}

This repon was prepared as an account of work sponso ed by an agency of the United States Government. Neither the United States Government nor any agency thereof, nor Battelle Memorial Institute, nor any or their employees, makes any warranty, expressed or implied, or assumes any legal liability or responsibility for the accuracy, completeness, or usefulness of any information, apparatus, product, or process disclosed, or represents that its use would not infringe privately owned rights. Reference herein to any specific commercial product, process, or service by trade name, trademark, manufacturer, or otherwise does not necessarily constjtute or imply its endorsement, recommendation, or favoring by the United States Government or any agency thereof, or Battelle Mernorial Institute. The views and opinions of authors expressed herein do not necessarily state or reflect those of the United States Government or any agency thereof.

\author{
PACIFIC NORTHWEST LABORATORY \\ operated by \\ BATTELLE MEMORIAL INSTITLITE \\ for the \\ UNITED STATES DEPARTMENT OF INERGY \\ under Contract DE-AC06-76RLO 1830
}

\author{
Printed in the United States of America \\ Available from \\ Nationat Technical Information Service \\ United States Department oi Commerce \\ $\$ 285$ Port Royal Road \\ Springfield, Virgina 22161 \\ NTIS Price Codes \\ Nicrotiche A01 \\ Printed Copy
}

$\begin{array}{cc}\text { Pages } & \begin{array}{c}\text { Price } \\ \text { Codes }\end{array} \\ 001-025 & \text { A02 } \\ 026-050 & \text { A03 } \\ 051-075 & \text { A04 } \\ 076-100 & \text { A05 } \\ 101 \cdot 125 & \text { A06 } \\ 126-150 & \text { A07 } \\ 151-175 & \text { A08 } \\ 176-200 & \text { A09 } \\ 201-225 & \text { A10 } \\ 226-250 & \text { A11 } \\ 257-275 & \text { A12 } \\ 276-300 & \text { A13 }\end{array}$


PNL -6818

UC -423

First Annual Progress Report

BEATRIX - I I PROGRAM

January 1988 to December 1988

ANNEX-III to IEA Implementing Agreement

for a Programme of Research and Development

on Radiation Damage in Fusion Materials

G. W. Hollenberg

March 1989

Prepared for

the U.S. Department of Energy

under Contract DE-AC06-76RLO 1830

Pacific Northwest Laboratory

Richland, Washington 99352 


\section{.}

1 


\section{EXECUTIVE SUMMARY}

During 1988, the BEATRIX-II program, Phase I was initiated by the signing of ANNEX-III and progressed through design efforts into either partial or complete fabrication of its systems in order to meet a scheduled beginning of irradiation in April 1989. Adequate funds were made available by Canada, Japan, and the U.S. to pursue the design and fabrication program at Pacific Northwest Laboratory (PNL), Westinghouse Hanford Company and Atomic Energy of Canada Limited (AECL). In addition, the Japan Atomic Energy Research Institute (JAERI) fabricated ceramic electrolysis cells (CEC) for incorporation into the sweep gas analysis iines. It appears that the final tasks before insertion into the reactor will be completed in time. Both the International Energy Agency (IEA) and Hanford site design review meetings have approved the finat design of the system.

The purpose of BEATRIX-II is to conduct an in-situ tritium recovery experiment in the high energy neutron environment of the Fast Flux Test Facility (FFTF). During Phase I, two in-situ capsules containing $L i_{2} O$ are being irradiated with higher tritium production levels than in previous experiments. One capsule possesses the capacity for temperature change experiments while the other possesses a temperature gradient for evaluating the stability of temperatures in an engineering blanket configuration. Nonvented capsules were included for measurement of irradiation damage, thermal diffusivity, PIE release kinetics, and beryliium compatibility.

Special materials and components were developed and adopted for BEATRIX-II including a channeled nickel layer, tritium barrier coatings, self-powered neutron detectors, tritium removal system, etc. Many of these materials and components could have application in future blanket systems. By December 1988, in-situ tritium recovery canisters had been fabricated and material for nonvented capsules were at Westinghouse Hanford. In December 1988, all sweep gas analysis system components had been received and were being installed into the glovebox before checkout.

A proposal was made to ship the tritium produced in the Phase I test and accumulated in the tritium removal system getter beds to the tritium system 
test assembly (TSTA) at Los Alamos National Laboratory (LANL). The tritium will be processed into a form compatible with fusion fueling, thus demonstrating the fuel cycle. The scope of Phase II, i.e., Cycle 12, irradiations will be determined in February 1989. 


\section{CONTENTS}

EXECUTIVE SUMMARY

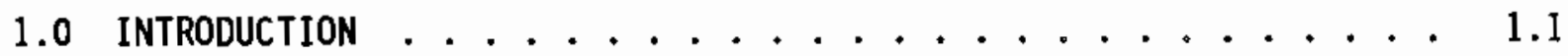

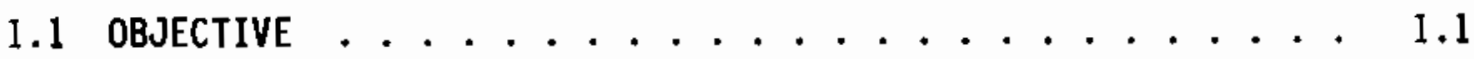

$1.2 \mathrm{SCOPE} \ldots \ldots \ldots \ldots \ldots \ldots \ldots$

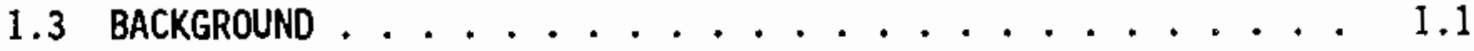

I.4 RESPONSIBILITIES . . . . . . . . . . . . . . 1.3



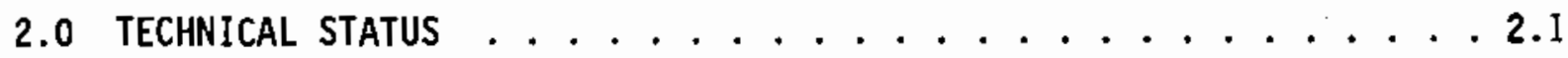

2.1 DESIGN DESCRIPTION . . . . . . . . . . . . 2.1

2.2 ACCOMPLISHMENTS . . . . . . . . . . . . . 2.9

2.3 COMPONENTS . . . . . . . . . . . . . . . . 2.9

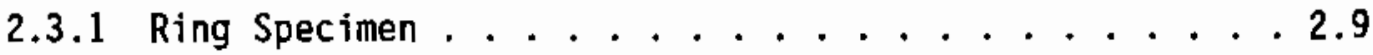

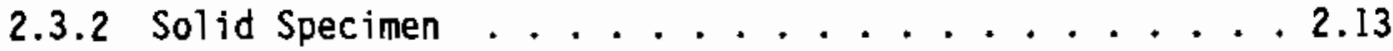

2.3.3 Barrier Coating .............. . . . . . . . .

2.3.4 Channeled Nickel Layer . . . . . . . . . . 2.13

2.3.5 Nonvented Specimens . . . . . . . . . . 2.16

2.3.6 Self-Powered Neutron Detector . . . . . . . . 2.17

2.3.7 Instrument and Control System . . . . . . . 2.18

2.3.8 Material Open Test Assembly . . . . . . . . 2.19

2.4 TRITIUM HANDLING SYSTEM . . . . . . . . . 2.20

2.4.I Glovebox Modifications .............2.20

2.4 .2 Glovebox Cleanup System ............. 2. . . . .

2.4.3 Gas Analysis System . . . . . . . . . . . 2.22

2.4.4 Ceramic Electrolysis Cell . . . . . . . . 2.22 
2.4.5 Inlet Monitoring and Control System . . . . . 2.22

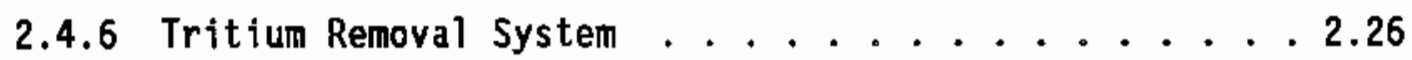

2.4.7 Tritium Ion Chambers ............ 2.26

2.4 .8 FFTF Installation . . . . . . . . . 2.26

2.4.9 BEATRIX-II Data Acquisition System ...... 2.28

2.5 DATA ANALYSIS . . . . . . . . . . . . . 2.29

2.6 TRITIUM SYSTEMS TEST ASSEMBLY INTERFACE . . . . . . . 2.32

2.7 PlanNed ACTIVItIES . . . . . . . . . . . . . . . . . . . . . .



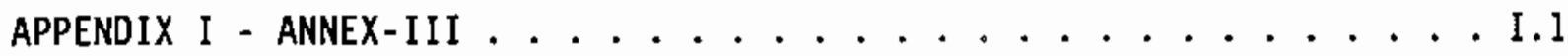
APPENDIX II - INTELLECTUAL PROPERTY OF BEATRIX-II PROGRAM. . . . . . II.I APPENDIX III - DOCUMENTATION OF BEATRIX-II PROGRAM . . . . . . . III.I APPENDIX IV - TSTA PROCESSING OF BEATRIX-II TRITIUM. . . . . . . . . IV.I 


\section{FIGURES}

1 A Fusion Materials Open Test Assembly (MOTA) Showing Canisters Attached to the Central Stalk and a Standard MOTA Canister with Temperature Control Capabilities Through Gas Gap Compositional Control ................ 2.2

2 The Ring Specimen Canister Design with Temperature Control and In-situ Tritium Recovery. .............. 2.4

3 The Solid Specimen Canister Design with Centerline Temperature Stability Measurements and In-situ Tritium Recovery....... . 2.4

4 Predicted Radial Temperature Gradients in the Ring and Solid Specimens ..................... 2.6

5 Tritium Production Gradients in the Solid Pellet Specimen . . . . 2.7

6 Sweep Gas Flow in the BEATRIX-II Experiment . . . . . . . . 2.8

7 The Thin-walled $\mathrm{Li}_{2} \mathrm{O}$ Specimens for Ring Specimen Canister . . . . 2.1I

8 Loading of the Ring Specimen into the Inner Cladding

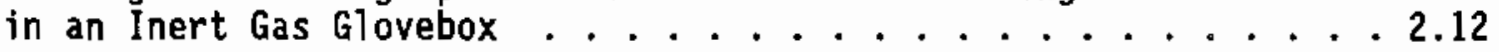

9 Loading of the Solid Pellets into the Solid Pellet Canister for BEATRIX-II, Cycle 11. . . . . . . . . . . 2.14

10 Micrograph of Tritium Barrier Coating Applied to Ring Specimen Canjster ................ 2.14

11 Micrograph of ChanneTed Nickel Layer on Cladding of Sol id Specimen Canister . . . . . . . . . . . 2.15

12 The Instrument and Control System (I\&C) Before Shipment to FFTF

13 Fusion MOTA Test Vehicle Fabrication Status as of December 1988 ................. . . 2.19

14 Tritium Glovebox Before Being Modified for BEATRIX-II . . . . . 2.21

15 Tritium Handling System Including Glovebox and Data Acquisition System During Operating Agent On-site Review Early in December 1988

16 Valving Pattern for the Gas Analys is System of BEATRIX-II . . . 2.23 
17 Tritium Handling System Instrumentation which Includes the Data Acquisition System . . . . . . . . . . 2.24

18 Testing of BEATRIX-II's Ceramic Electrolysis Cells from JAERI in October $1988 \ldots \ldots . \ldots . . \ldots 2 . \ldots . . \ldots 24$

19 Inlet Monitoring System in December $1988 \ldots \ldots . \ldots . \ldots 2.25$

20 In iet Pressure Control System in December $1988 \ldots \ldots . \ldots 2.27$

21 Tritium Removal System in November $1988 \ldots \ldots 28$

\section{TABLES}

11988 Chronology of BEATRIX-1I. . . . . . . . . . . 1.2

2 BEATRIX-II/ANNEX-III Responsibilities. . . . . . . . . 1.4

3 Funding Requirements per ANNEX-III for BEATRIX-II, Phase I . . . 1.6

4 MOTA-2A (Fusion MOTA) Canister Matrix. . . . . . . . 2.3

5 Characterization of the $\mathrm{Li}_{2} \mathrm{O}$ Specimens and Anticipated

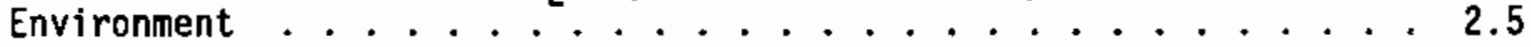

6 BEATRIX-II, Phase I, Cycle 11, Test Schedule 1988. . . . . . 2.10

7 BEATRIX-II Nonvented Capsule Matrix. . . . . . . . . . 2.16

8 Experimenter BEATRIX-II Channels . . . . . . . . . . 2.30

9 BEATRIX-II, Cycle 11, Preliminary Test Scenario. . . . . . . 2.32

10 BEATRIX-II, Phase I, Cycle 11, Planned Activities. . . . . . 2.33 


\subsection{INTROOUCTION}

\subsection{OBJECTIVE}

The objective of the BEATRIX-II experiment is to design, conduct, and evaluate a collaborative, in-situ tritium-recovery experiment in the Fast Flux Test Facility (FFTF). Continuous monitoring of candidate solid breeder material's performance with respect to thermat conductivity, temperature stability, and tritium release is to be accomplished up to extended lithium burnup levels under simulated blanket environments.

\subsection{SCOPE}

The BEATRIX-II experiment as described in ANNEX-III is divided into Phase I and Phase II. The Phase I activities are directed specifically at the irradiation of material in the cycle 11 of FFTF, beginning approximately on April 1989 and continuing to April 1990. Phase II will be irradiations conducted in Cycle 12 of FFTF, from approximately April 1990 to April 1991. Phase II activities are undefined at this time.

The Phase I scope includes the irradiation of two in-situ tritium recovery capsules containing $L_{i}{ }_{2}$. The ring specimen or temperature-change capsule is designed to operate in a manner similar to previous tritium recovery experiments, i.e. TRIO, VOM, CRITIC, etc. The solid specimen capsule will provide performance data on a large mass of $\mathrm{Li}_{2} \mathrm{O}$ irradiated under a temperature gradient. Nonvented capsules were selected for other canisters.

\subsection{BACKGROUND}

This report covers the first year of BEATRIX-II. A chronology of the International Energy Agency (IEA) major events is given in Table 1. Annex III, see Appendix I, was submitted by the Executive Committee to the IEA for approval during January 1988. Letters-of-intent preceded the actual transfer of funds to the operating agent, the U.S. Department of Energy (DOE). Events relative to the execution of the experiment and financial matters will be dealt with later in this report. 
IABLE 1. 1988 Chronotogy of BEATRIX-II

\begin{tabular}{|c|c|c|c|}
\hline Date & Event/Location & Participant (a) & Impact \\
\hline 15 January 1988 & $\begin{array}{l}\text { Interim Design } \\
\text { Review }\end{array}$ & $\begin{array}{l}\text { BII Working } \\
\text { Group }\end{array}$ & $\begin{array}{l}\text { Technical } \\
\text { Approval to } \\
\text { proceed }\end{array}$ \\
\hline 22 January 1988 & Annex III to IEA & $\begin{array}{l}\text { IEA Executive } \\
\text { Committee }\end{array}$ & $\begin{array}{l}\text { Formal } \\
\text { Authorization }\end{array}$ \\
\hline 8-9 March 1988 & $\begin{array}{l}\text { Final Design } \\
\text { Review, } \\
\text { Richland, WA, } \\
\text { USA }\end{array}$ & $\begin{array}{l}\text { BII Working } \\
\text { Group plus } \\
\text { experts }\end{array}$ & $\begin{array}{l}\text { Design Approval/ } \\
\text { Modifications }\end{array}$ \\
\hline 19 Apri1 1988 & $\begin{array}{l}\text { "Approval-in- } \\
\text { Principle" } \\
\text { granted }\end{array}$ & DOE & $\begin{array}{l}\text { Authorization to } \\
\text { use FFTF }\end{array}$ \\
\hline 19 April 1988 & $\begin{array}{l}\text { BII Meeting, } \\
\text { Tokyo, Japan }\end{array}$ & $\begin{array}{l}\text { BII Working } \\
\text { Group }\end{array}$ & Review Status \\
\hline 20 July 1988 & $\begin{array}{l}\text { Solid Pellet } \\
\text { Shipment }\end{array}$ & JAERI & $\begin{array}{l}\text { Acceptance } \\
\text { Testing }\end{array}$ \\
\hline August 1988 & $\begin{array}{l}\text { Ring Specimen } \\
\text { Fabrication }\end{array}$ & PNL & $\begin{array}{l}\text { Acceptance } \\
\text { Testing }\end{array}$ \\
\hline $\begin{array}{l}10 \text { September to } 8 \\
\text { October } 1988\end{array}$ & $\begin{array}{l}\text { Technical } \\
\text { Meeting, } \\
\text { Richland, WA, } \\
\text { USA }\end{array}$ & $\begin{array}{l}\text { T. Kurasawa, } \\
\text { JAERI }\end{array}$ & $\begin{array}{l}\text { CEC Checkout } \\
\text { etC. }\end{array}$ \\
\hline 23 November 1988 & $\begin{array}{l}\text { TRS \& Ion } \\
\text { Chambers Arrive } \\
\text { Hanford }\end{array}$ & $\mathrm{AECL}$ & $\begin{array}{l}\text { Acceptance } \\
\text { Review }\end{array}$ \\
\hline 28 November 1988 & $\begin{array}{l}\text { Nonvented } \\
\text { Specimens } \\
\text { Fabricated }\end{array}$ & PNL/JAERI & $\begin{array}{l}\text { Acceptance } \\
\text { Testing }\end{array}$ \\
\hline 7 December 1988 & $\begin{array}{l}\text { Program Review, } \\
\text { Richland, WA, } \\
\text { USA }\end{array}$ & $\begin{array}{l}\text { Operating Agent, } \\
\text { TC Reuther }\end{array}$ & $\begin{array}{l}\text { Review of } \\
\text { Program Status }\end{array}$ \\
\hline
\end{tabular}

(a) BII = BEATRIX - II 
It is evident that many beyond the work scope at the Hanford site have contributed to the progress in this program. The BEATRIX-II Working Group conducted interim and final design reviews of the BEATRIX-II experiment proposals during 1988. In addition to experts from Japan Atomic Energy Research Institute (JAERI), Atomic Energy of Canada Limited (AECL), Pacific Northwest Laboratory (PNL) ${ }^{(a)}$, and Westinghouse Hanford Company, others from the tritium system test assembly (TSTA) at the Los Alamos National Laboratory (LANL), Argonne National Laboratory (ANL), and University of California Los Angeles (UCLA) also participated in these reviews. The delivery of CEC cells and $\mathrm{Li}_{2} \mathrm{O}$ pellets from JAERI and the ion chambers and tritium removal system from $A E C L$ are examples of activities conducted of $f$ the Hanford site. The presence of $T$. Kurasawa during the checkout of the CEC cells specifically accelerated that procedure.

Design activities changed to fabrication and procurement activities after the March 1988 final design review. Li ${ }_{2} 0$ test material for both capsules became available during the summer of 1988. The tritium analysis glovebox assembly was accelerated in 0ctober 1988. The tritium removal system from AECL was not deTivered until November 1988 because of delays associated with obtaining an export license. Finally, at year's end, the in-reactor portions of the BEATRIX-II experiment were assembled and attached to the Materials Open Test Assembly (MOTA) stalk while the glovebox and its internal panels were being assembled for final inspection before installation in FFTF scheduled for the first week of February 1989. Intellectual property and documentations of BEATRIX-II in 1988 are 1 isted in Appendices II and III.

\subsection{RESPONSIBILITIES}

The responsible parties associated with the BEATRIX-II experiment and ANNEX-III are shown in Table 2. The IEA executive committee has the responsibility for the approval and signing of Annex-III. According to ANNEX-III, the BEATRIX-II Working Group is a technical steering committee for preparation and supervision of budgets, schedules, and scientific activities of the tasks associated with BEATRIX-II. The operating agent for BEATRIX-II is DOE,

(a) Operated for the U.S. Department of Energy by the Battelle Memorial Institute. 
IABLE 2. BEATRIX-II/ANNEX III Responsibilities

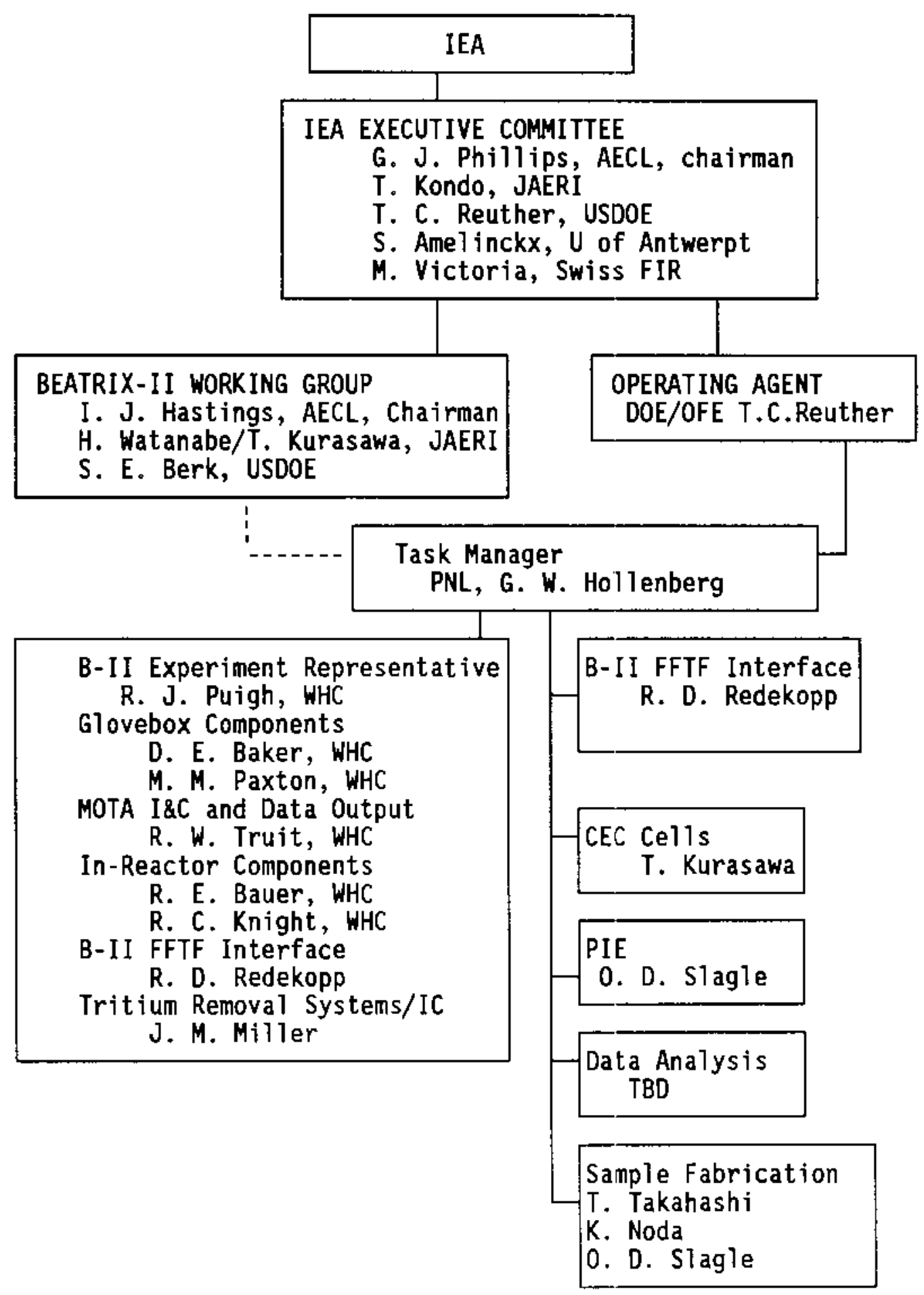


Office of Fusion Energy (OFE) (T. C. Reuther) which performs all legal actions required for ANNEX-III in addition to invoicing and accounting for funds. A PNL task manager at the Hanford site, Richland, WA, monitors the progress and coordinates activities between the participants. The funding provided by Japan, Canada (through the National Fusion Program, Canadian Fusion Fuels Technology Project and AECL) and the U.S. supports activities at the Westinghouse Hanford which operates the FFTF for the design, construction and operation of the BEATRIX-1I experiment. Dr. R. J. Puigh is the experimenter's representative for this experiment. At the FFTF reactor, Mr. R. E. Redekopp is the site representative. J. M. Miller is responsible for the tritium removal system and ion chambers acquired from AECL. Dr. Kurasawa is responsible for the ceramic electrolysis cells (CEC) provided by JAERI. Post-irradiation examination will be the responsibility of Dr. 0. D. Slagle. The responsibilities associated with the data analysis and reporting are to be decided by the BEATRIX-II working group.

\subsection{SCHEDULE AND COSTS}

The funding for BEATRIX-II has been divided into Phase I and Phase II activities. The funding requirements for BEATRIX-II, Phase I, were documented in ANNEX-III and are listed in Table 3. Also in Table 3 are the funds received from the participants during U.S. FY 1987 and 1988. It is anticipated that the Phase II will be defined at a BEATRIX-II Working Group Meeting scheduled for 13 February 1989 in Seattle, Washington. The scope of activities for Phase II, i.e. the Cycle 12 irradiation, will be defined at that time.

As reported in detail 1ater, BEATRIX-II, Phase I, tasks are progressing at a rate consistent with insertion into FFTF for irradiation during Cycle 11. Projections for the beginning of Cycle 11 are now 29 April 1989 instead of January 1989. Because of the delayed insertion date, expenditure rates were less than estimated at the end of U.S. FY 1988 for the entire MOTA. 
TABLE 3. Funding Requirements per ANNEX-III for BEATRIX-II, Phase I

Participant

Canada

Japan

United States

\begin{tabular}{lrrr}
\multicolumn{4}{c}{ U.S. FY, USKS } \\
\hline 1987 & $\underline{1988}$ & $\underline{1989}$ & $\underline{1990}$ \\
-- & 78 & 39 & - \\
400 & 443 & 318 & 91 \\
180 & 524 & 327 & 220
\end{tabular}

Funds Received-to-Date (1 October 1988)

Participant

Canada

Japan

United States

\begin{tabular}{llll}
\multicolumn{4}{c}{ U.S. FY, USK\$ } \\
\hline$\underline{1987}$ & $\underline{1988}$ & $\underline{1989}$ & $\underline{1990}$
\end{tabular}

$60(a)$

$400 \quad 443$

$180 \quad 524 \quad 327$

(a) Note: Canada has not been invoiced for the additional 18K after an initial 60K contribution. 


\subsection{IECHNICAL STATUS}

Liquid Metal reactor canisters will be inserted in the fusion MOTA on an exchange basis with the U.S. fusion program in order to avoid any irradiated materials during assembly of this MOTA.

\subsection{DESIGN DESCRIPTION}

The BEATRIX-II, Phase I, Cycle 11, will consist of both vented and nonvented capsules irradiated for approximately one year in the FFTF. These specimens have been loaded into canisters such as the ones shown in Figure 1 which will be irradiated in Cycle 11. The BEATRIX-II canister locations in the fusion MOTA are designated IEA in Table 4 in contrast to other MOTA users, Monbusho and the U.S. fusion program. The numerical designations refer to the axial row of the canister while the alphabetic designations refer to six different radial positions around the central MOTA stalk. The nonvented capsules of the BEATRIX-II, Phase I test will be loaded into standard MOTA canisters $1 \mathrm{~B}, 1 \mathrm{D}, 5 \mathrm{E}$, and $8 \mathrm{~B}$ (see Table 4 ). The fusion MOTA will also contain two specialized canisters, $1 \mathrm{C}$ and $\mathrm{IE}$, for the two vented specimen geometries.

The ring specimen canister is designed to provide tritium release and thermal conductivity data on $\mathrm{Li}_{2} \mathrm{O}$. The canister's design (shown in Figure 2) allows temperature changes and has a sweep gas flow through the canister to recover the released tritium. The solid pellet specimen canister (shown in Figure 3 ) is designed to provide tritium release data for $\mathrm{Li}_{2} \mathrm{O}$ under the large thermal gradient $\left(-450^{\circ} \mathrm{C}\right)$ prototypic of many fusion blanket design. The sweep gas flow in the solid pellet geometry canister is routed around the pellets through a channeled nickel layer which is located next to the outer circumference of the solid $\mathrm{Li}_{2} \mathrm{O}$ pellets. To minimize the permeation of tritium into the reactor sodium the canister walls and the exit, sweep gas lines for both in-situ recovery canisters are coated with a tritium barrier. A self-powered neutron detector (SPND) is located next to the vented canisters to provide information on temporal variations in the local neutron flux.

The major characteristics of the $\mathrm{L}_{2} \mathrm{O}$ specimens and their anticipated environment are summarized in Table 5 . The ${ }^{6} \mathrm{Li}$ enrichment for both specimens 


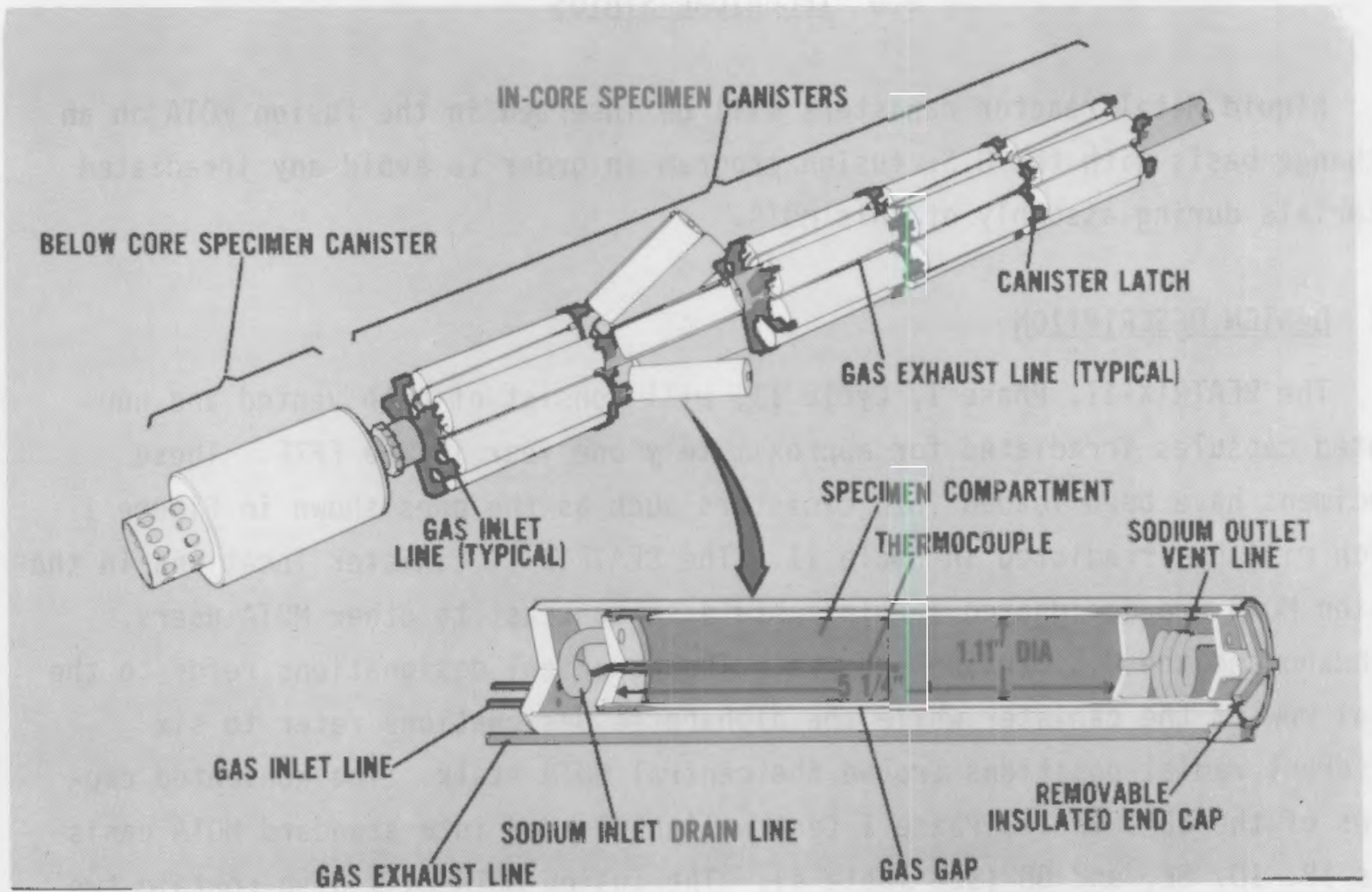

FIGURE 1. A Fusion MOTA Test Assembly Showing Canisters Attached to the Central Stalk and a Standard MOTA Canister with Temperature Control Capabilities Through Gas Cap Compositional Control. Some canisters (weeper) are maintained at reactor coolant temperatures. (Neg. 8405218-1CN) 
TABLE 4. MOTA-2A (Fusion MOTA) Canister Matrix

\begin{tabular}{|c|c|c|c|c|c|c|}
\hline & A & B & C & D & $E$ & $F$ \\
\hline 8 & $\begin{array}{c}440^{\circ} \mathrm{C} \\
\text { FUSION } \\
\text { [offset] } \\
W \quad \text { (HHF) }\end{array}$ & $\begin{array}{c}440^{\circ} \mathrm{C} \\
\text { FUS /MONB/ } \\
\text { IEA } \\
W\end{array}$ & & & & \\
\hline 7 & & $\begin{array}{c}435^{\circ} \mathrm{C} \\
\text { FUS } / \text { MONB } \\
\text { W }\end{array}$ & & & & \\
\hline$\sigma$ & $\begin{array}{c}430^{\circ} \mathrm{C} \\
\text { FUSION } \\
\text { [offset] } \\
W \quad(H H F)\end{array}$ & $\begin{array}{l}430^{\circ} \mathrm{C} \\
\text { FUS/MONB } \\
\text { W }\end{array}$ & $\begin{array}{c}430^{\circ} \mathrm{C} \\
\text { MONB } \\
\text { [offset] } \\
W^{\text {offHF) }}\end{array}$ & & & \\
\hline 5 & $\begin{array}{r}600^{\circ} \mathrm{C} \\
\text { FUSION } \\
\text { [offset] } \\
\text { (HHF) }\end{array}$ & $\begin{array}{c}425^{\circ} \mathrm{C} \\
\text { FUSION } \\
\text { [offset] } \\
\mathrm{W}^{\text {off }} \text { (HHF) }\end{array}$ & $\begin{array}{l}600^{\circ} \mathrm{C} \\
\text { FUSION } \\
\text { [offset] } \\
\text { (HHF) }\end{array}$ & $\begin{array}{l}800^{\circ} \mathrm{C} \\
\text { MONB }\end{array}$ & $\begin{array}{c}425^{\circ} \mathrm{C} \\
\text { IEA/MONB } \\
W\end{array}$ & $\begin{array}{l}600^{\circ} \mathrm{C} \\
\text { MONB }\end{array}$ \\
\hline 4 & $\begin{array}{l}425^{\circ} \mathrm{C} \\
\text { LMR } \\
W\end{array}$ & $\begin{array}{l}600^{\circ} \mathrm{C} \\
\text { FUSION }\end{array}$ & $\begin{array}{l}600^{\circ} \mathrm{C} \\
\text { FUSION }\end{array}$ & $\begin{array}{l}425^{\circ} \mathrm{C} \\
\text { MONB } \\
W\end{array}$ & $\begin{array}{l}520^{\circ} \mathrm{C} \\
\text { MONB }\end{array}$ & $\begin{array}{l}600^{\circ} \mathrm{C} \\
\text { MONB }\end{array}$ \\
\hline 3 & $\begin{array}{l}605^{\circ} \mathrm{C} \\
\text { LMR }\end{array}$ & $\begin{array}{l}550^{\circ} \mathrm{C} \\
\text { LMR }\end{array}$ & $\begin{array}{l}420^{\circ} \mathrm{C} \\
\text { FUSION }\end{array}$ & $\begin{array}{l}420^{\circ} \mathrm{C} \\
\text { MONB } \\
W\end{array}$ & $\begin{array}{l}520^{\circ} \mathrm{C} \\
\text { MONB }\end{array}$ & $\begin{array}{l}600^{\circ} \mathrm{C} \\
\text { MONB }\end{array}$ \\
\hline 2 & $\begin{array}{ll} & 410^{\circ} \mathrm{C} \\
& \text { LMR } \\
W & \end{array}$ & $\begin{array}{cc} & 410^{\circ} \mathrm{C} \\
& \text { LMR } \\
W & \end{array}$ & $\begin{array}{l}520^{\circ} \mathrm{C} \\
\text { FUSION }\end{array}$ & $\begin{array}{l}410^{\circ} \mathrm{C} \\
\text { MONB } \\
W\end{array}$ & $\begin{array}{l}410^{\circ} \mathrm{C} \\
\text { MONB } \\
W\end{array}$ & $\begin{array}{l}520^{\circ} \mathrm{C} \\
\text { MONB }\end{array}$ \\
\hline 1 & $\begin{array}{l}-390^{\circ} \mathrm{C} \\
\text { MONB } \\
W\end{array}$ & $\begin{array}{l}390^{\circ} \mathrm{C} \\
\text { IEA } \\
\text { W }\end{array}$ & $\begin{array}{c}900^{\circ} \mathrm{C} \\
\text { IEA } \\
{[3 \text { TCS }]} \\
\end{array}$ & $\begin{array}{r}390^{\circ} \mathrm{C} \\
\text { IEA } \\
\text { W }\end{array}$ & $\begin{array}{c}450-600^{\circ} \mathrm{C} \\
\text { IEA } \\
{[3 \mathrm{TCS}]}\end{array}$ & $\begin{array}{l}460^{\circ} \mathrm{C} \\
\text { MONB }\end{array}$ \\
\hline$B C$ & $\begin{array}{l}365^{\circ} \mathrm{C} \\
\text { FUSION } \\
W\end{array}$ & $\begin{array}{l}365^{\circ} \mathrm{C} \\
\text { FUSION } \\
W\end{array}$ & $\begin{array}{l}365^{\circ} \mathrm{C} \\
\text { LMR }\end{array}$ & $\begin{array}{ll} & 365^{\circ} \mathrm{C} \\
& \mathrm{LMR} \\
W & \end{array}$ & $\begin{array}{l}365^{\circ} \mathrm{C} \\
\text { MONB }\end{array}$ & $\begin{array}{l}410^{\circ} \mathrm{C} \\
\text { MONB }\end{array}$ \\
\hline
\end{tabular}

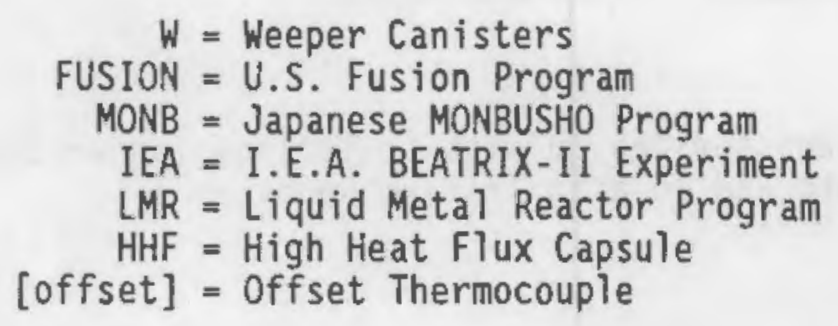




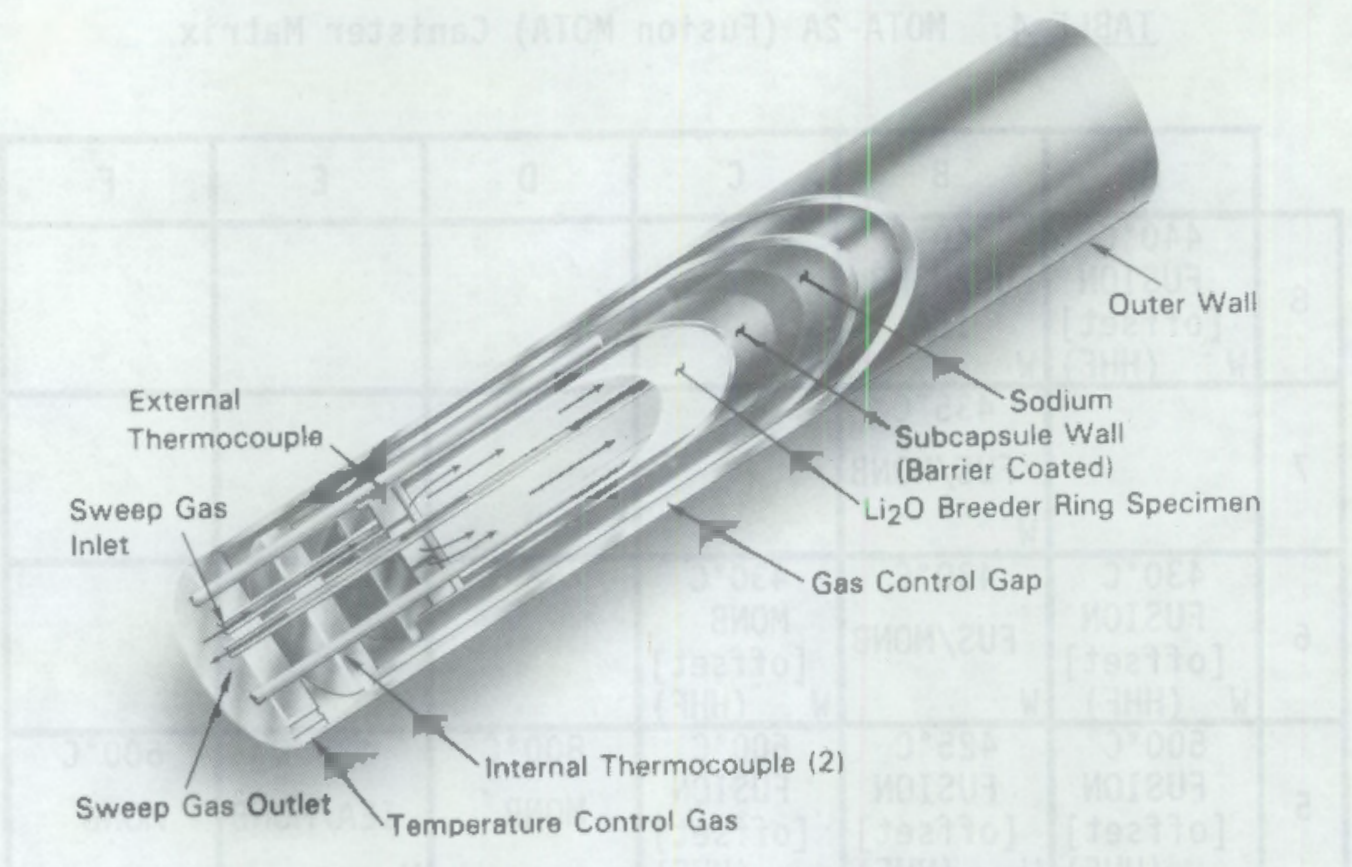

FIGURE 2. The Ring Specimen Canister Design with Temperature Control and In-situ Tritium Recovery (Neg. 88082331-2)

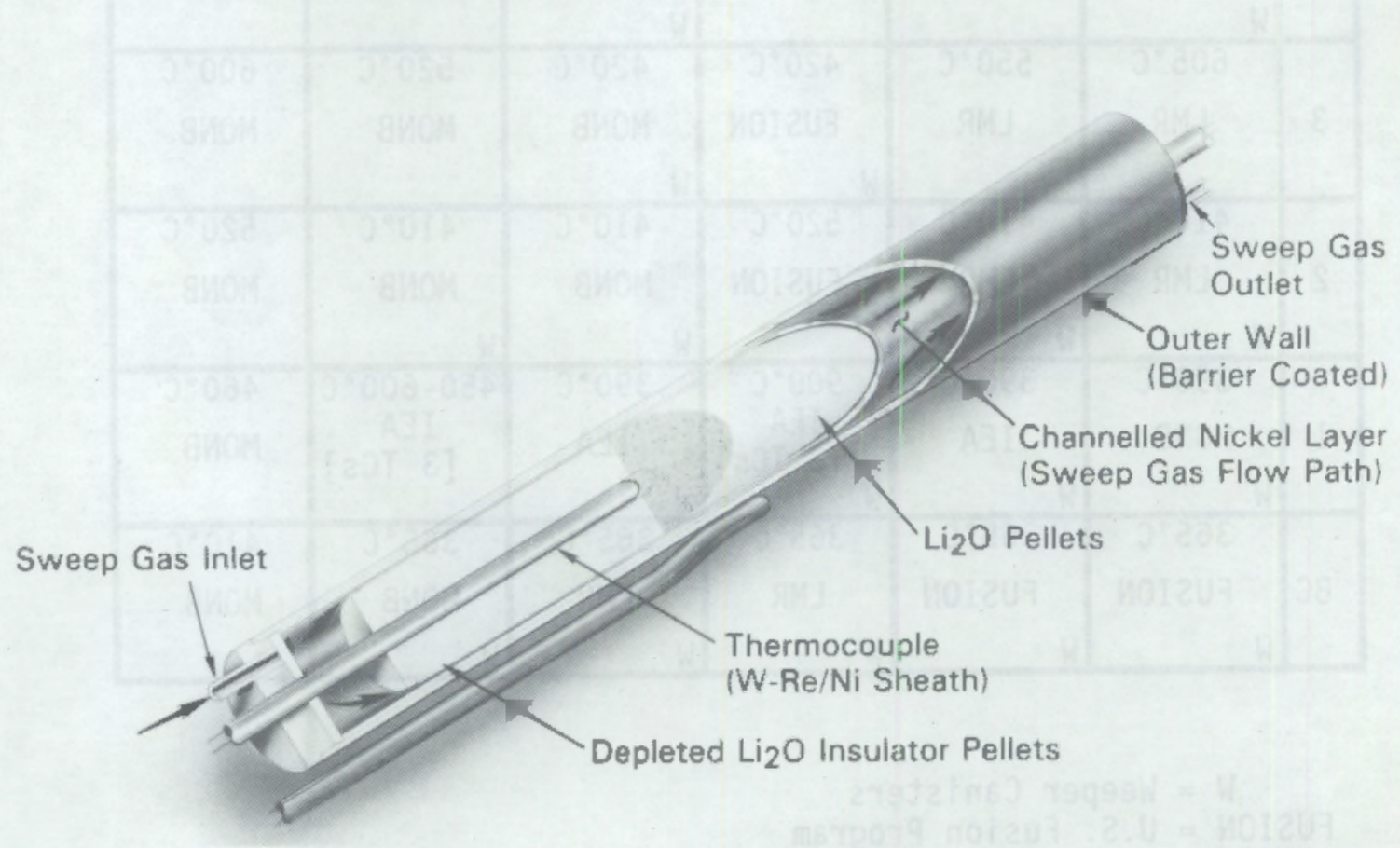

FIGURE 3. The Solid Specimen Canister Design with Centerline Temperature Stability Measurements and In-situ Tritium Recovery (Neg. 88082331-1) 
TABLE 5. Characterization of the $\mathrm{Li}_{2} \mathrm{O}$ Specimens and Anticipated Environment

Specimen

Physical Dimensions

Outside Diameter (mm)

Wall Thickness (mm) Length $(\mathrm{mm})$

Lithium-6 Enrichment (\%)

Density (\%TD)

Grain Size (um)

Irradiation Temperature

Inner Radius $\left({ }^{\circ} \mathrm{C}\right)$

Outer Radius $\left({ }^{\circ} \mathrm{C}\right)$

Maximum Gradient $\left({ }^{\circ} \mathrm{C}\right)$

Total Tritium Production (Ci)

Neutron Fluence

$\left(10^{22} \mathrm{n} / \mathrm{cm}^{2} \quad\right.$ E>0.1Mev)

Sweep Gas System

Gas Composition

Flow rates $\left(\mathrm{cm}^{3} / \mathrm{m}\right)$
Ring Specimen

18.57

1.50

88.9

61.0

80

5

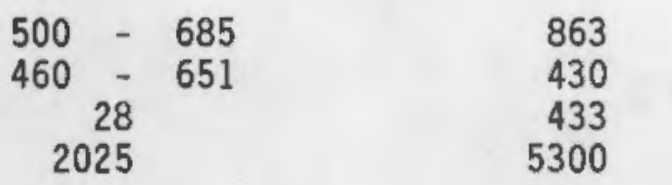

3.9

3.9

was chosen to obtain a 1 ithium atom burnup of $4 \%$ by the end of the irradiation (300 Equivalent Full Power Days). Monte Carlo neutronic calculations were performed to determine the reaction rate yielding the desired lithium atom burnup. Canisters are located near the bottom of the core in order to minimize the irradiation temperatures because the coolant is heated as it passes through the core. The dimensions of the ring geometry specimen were chosen to minimize the radial temperature gradient, maintain temperature control over an acceptable range and still generate significant tritium. The dimensions of the solid pellet geometry specimen were chosen to achieve an initial centerline temperature of approximately $900^{\circ} \mathrm{C}$. The calculated radial temperature gradients in the two specimen types are shown in Figure 4.

During the irradiation, the temperature of the ring specimen will be incrementally stepped from one temperature to another in order to observe the kinetics of tritium release from $\mathrm{Li}_{2} \mathrm{O}$. In the solid specimen, no external temperature changes will be made but the centerline thermocouple temperature will indicate the stability of thermal performance of $\mathrm{Li}_{2} \mathrm{O}$, thus establishing design margins. 


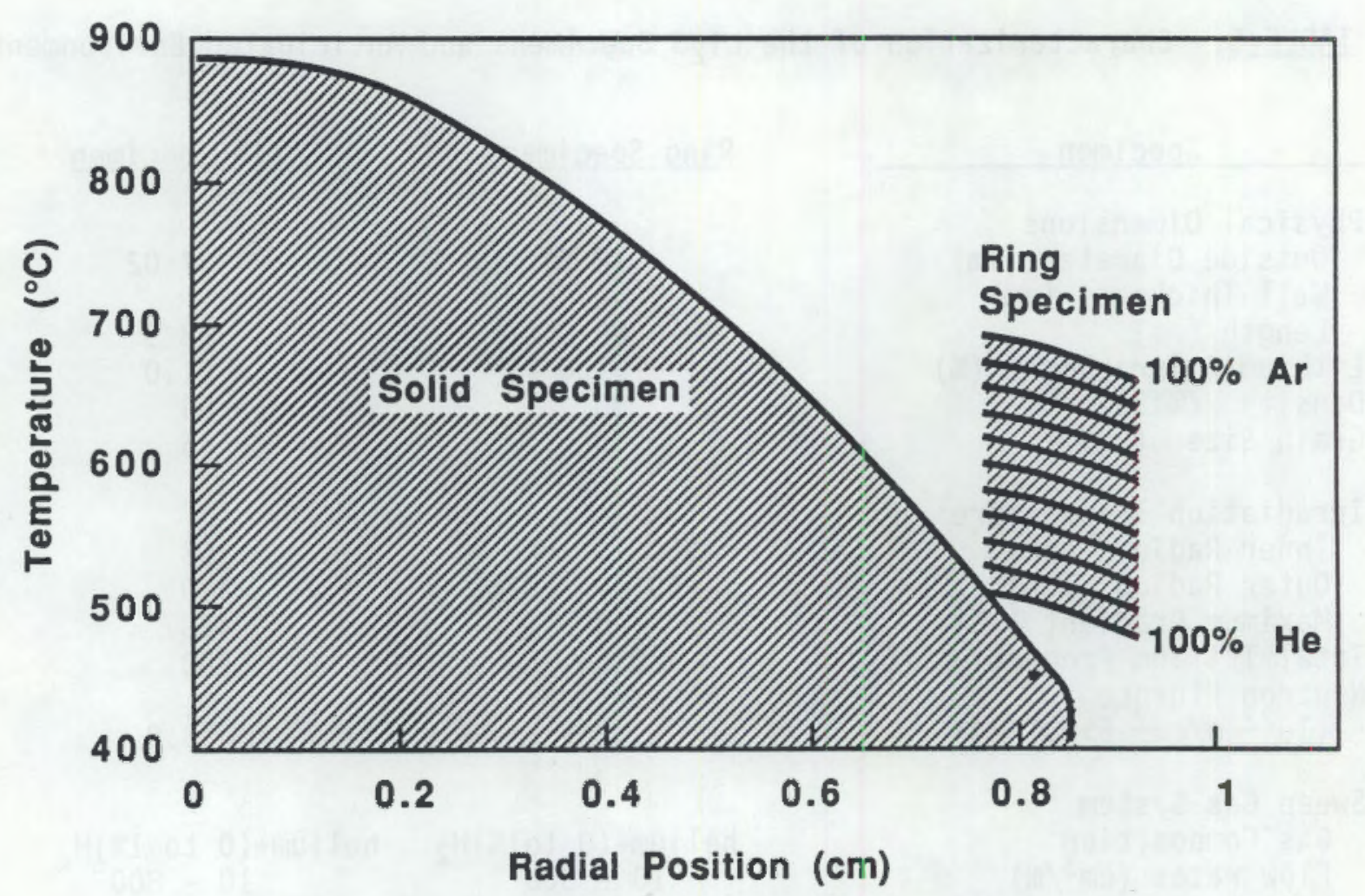

FIGURE 4. Predicted Radial Temperature Gradients in the Ring and Solid Specimens (Neg. 88090922-2)

The tritium production rate in the ring geometry specimen is calculated to be $7 \mathrm{Ci}$ /day which will provide $2025 \mathrm{Ci}$ by the end-of-life. The calculated tritium production gradients in the ring geometry specimen are calculated to be quite low $(<5 \%)$ because of lithium's relatively low average cross section for neutron reactions in FFTF's fast neutron environment. The calculated tritium production rate is $17 \mathrm{Ci} /$ day which will provide $5300 \mathrm{Ci}$ by the endof-life. The calculated radial and axial tritium production rate gradients in the solid pellet geometry specimen are shown in Figure 5 . As seen in the figure, both the axial and radial gradients are less than $7 \%$. Because of the higher tritium production rates in the BEATRIX-II experiment, it is possible to achieve $50 \mathrm{ppm}$ of tritium in the sweep gas at $100 \mathrm{~cm}^{3}$. Higher tritium partial pressures are typical for the recoverable levels in an actual blanket and should reduce the influence of minor impurities present in gasses (1 ppm). 


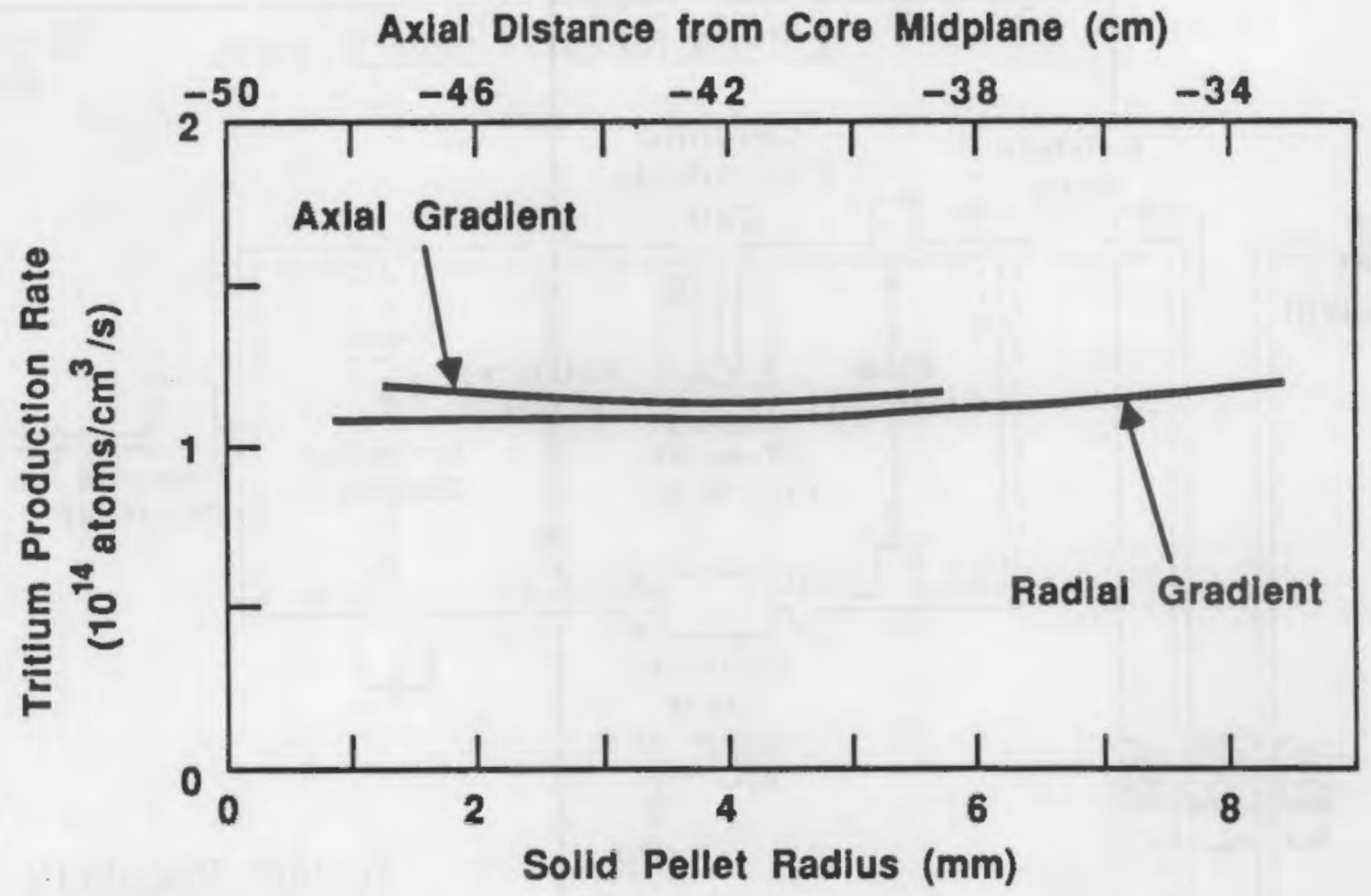

FIGURE 5. Tritium Production Gradients in the Solid Pellet Specimen

The sweep gas flow for the BEATRIX-II, Phase I test is shown in Figure 6 . The sweep gas flow for the vented canisters originates at the inlet monitoring system and flows to the inlet pressure control system before routing to the MOTA. These two systems comprise the gas inlet system. This design offers the flexibility of routing a separate sweep gas composition to each vented canister in the fusion MOTA. The sweep gas from each canister is routed out of the MOTA and to the gas analysis system where the flow stream from each canister is split into two paths. One path measures the total tritium in the sweep gas line; the second path measures the tritium gas $\left(H T+T_{2}\right)$ in the sweep gas line. The sweep gas flow from the two vented canisters is combined and processed through the tritium removal system which removes the tritium from the sweep gas before it is exhausted into the cell atmosphere processing system (CAPS) which is used by many systems in FFTF. Both the gas analysis system and the tritium removal system are located within a glovebox which provides environmental control and secondary containment for the tritium systems. 


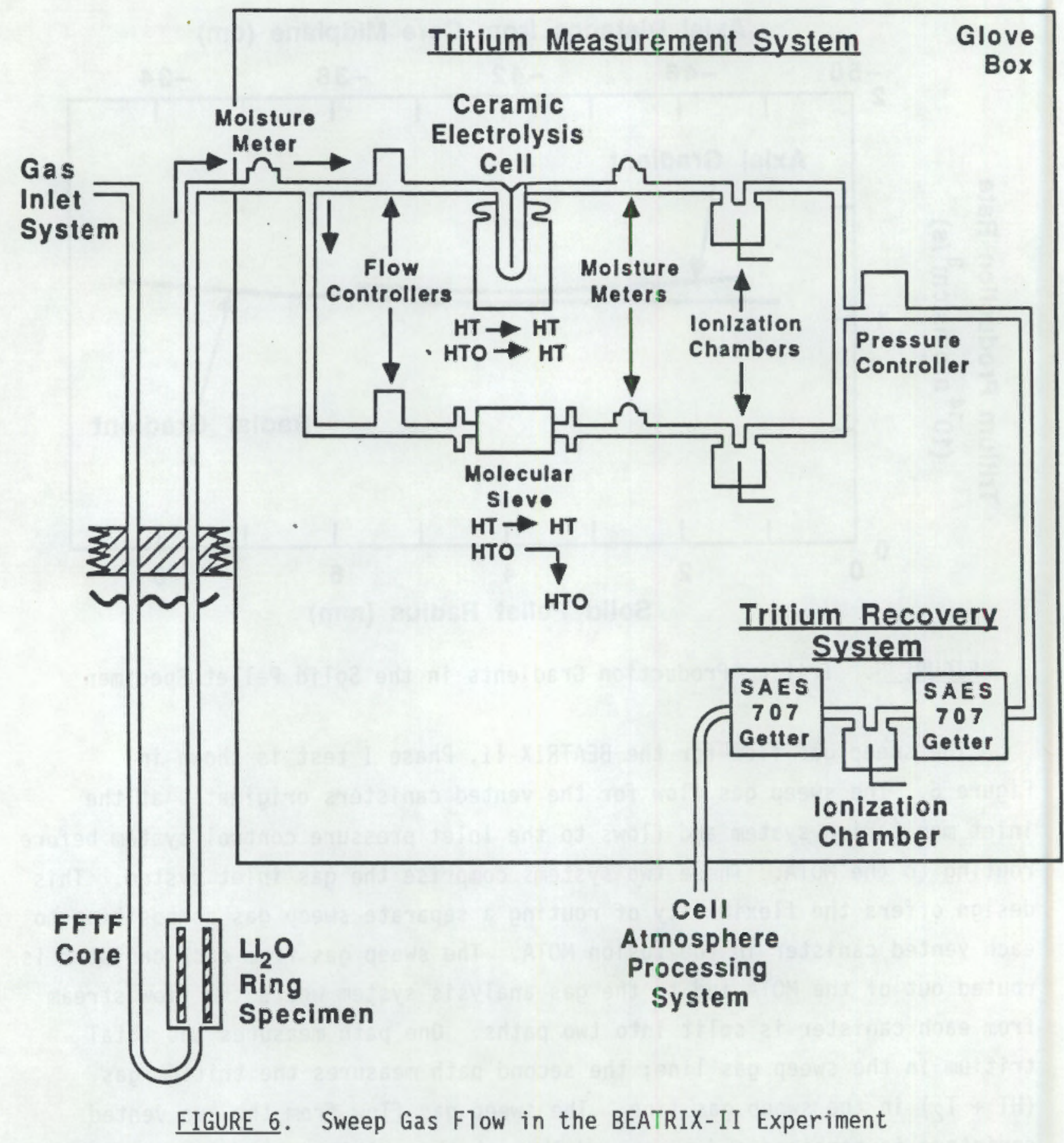




\subsection{ACCOMPLISHMENTS}

The schedule of activities performed on the BEATRIX-II experiment during calendar year 1988 are summarized in Table 6. Design work continued during the first part of the calendar year until the final design review by the IEA working group occurring in March 1988. An internal, Westinghouse Hanford design review was held in May 1988. The major efforts in 1988 were in the assembly of the vented canisters and the tritium handling system. Specimens for both the vented capsules were provided on schedule. The assembly of the solid pellet canister was completed in October and the assembly of the ring specimen canister was completed in December. Difficulties in obtaining qual ified weld procedures caused some delays in the assembly of these capsules. However, work then proceeded with the assembly of the fusion MOTA and the schedule remains viable for completion of the fusion MOTA before the start of the FFTF Cycle 11 which is presently planned for May 1989. The assembly of the MOTA instrumentation and control (I\&C) system has been completed and installation initiated at FFTF. The assembly of the tritium handling system (THS) is $95 \%$ completed. Canada completed the design, pretest characterization, and assembly of the tritium removal system and ion chambers required for the gas analysis system. These components were received at Westinghouse Hanford in November 1988. Initial checkout of the system is scheduled for January, before its shipment to FFTF for installation. Final installation checkout will occur in March and April of next year.

\subsection{COMPONENTS}

The in-reactor components will be attached to the MOTA test assembly; these components include the ring specimen and solid specimen canisters, nonvented canisters, and associated components.

\subsubsection{Ring Specimen}

A drawing of the ring specimen canister was presented in Figure 2. This canister has been fabricated and attached to the MOTA stalk. The ring specimen canister will allow temperature changes between $460^{\circ} \mathrm{C}$ and $650^{\circ} \mathrm{C}$ on a thin ring of $\mathrm{Li}_{2} \mathrm{O}$ in a manner similar to earlier experiments. In Figure 7 , the ring specimen is shown before loading into the canister. It was noted that 
TABLE 6. BEATRIX-II, Phase I, Cycle 11 Test Schedule 1988

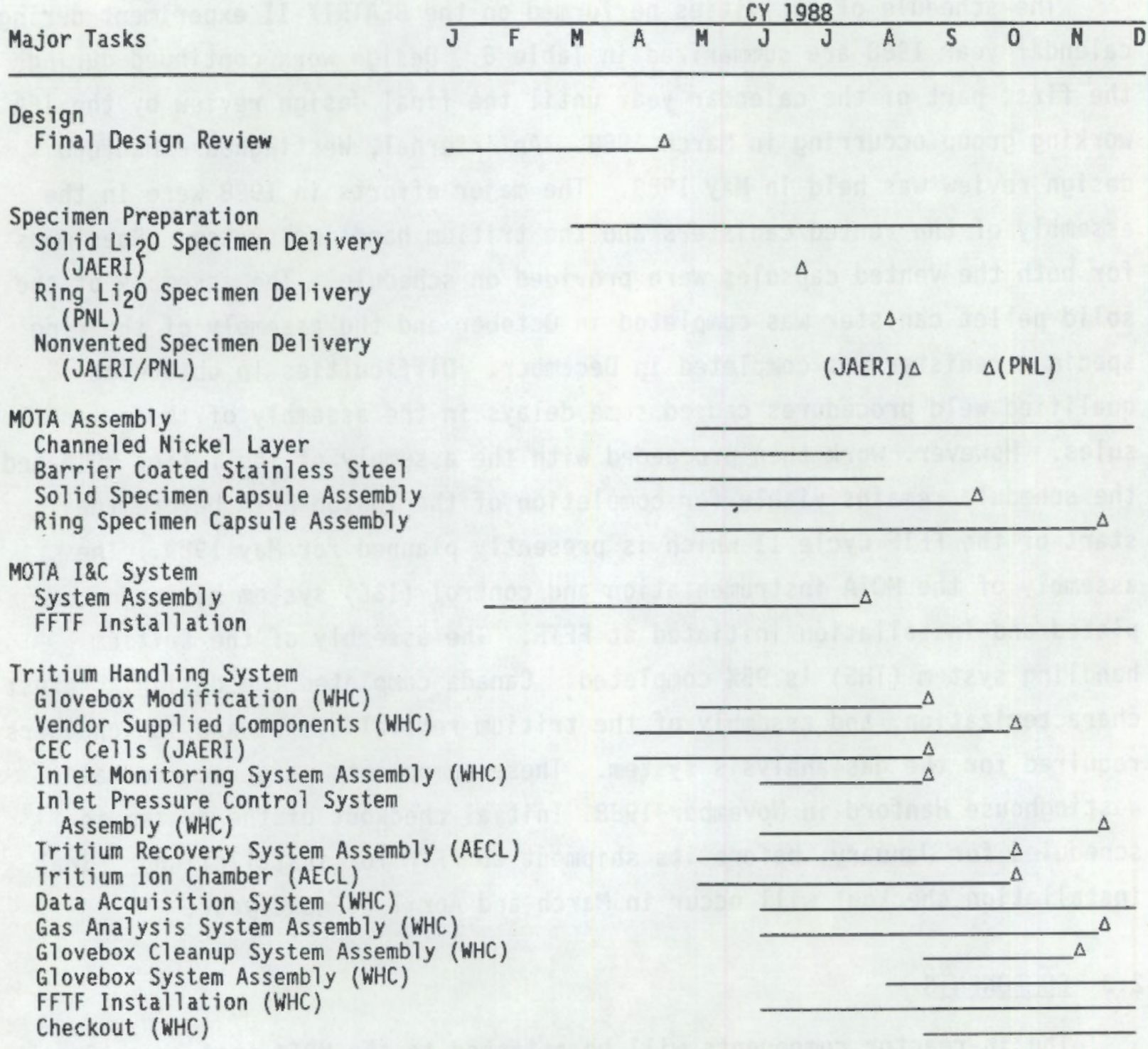




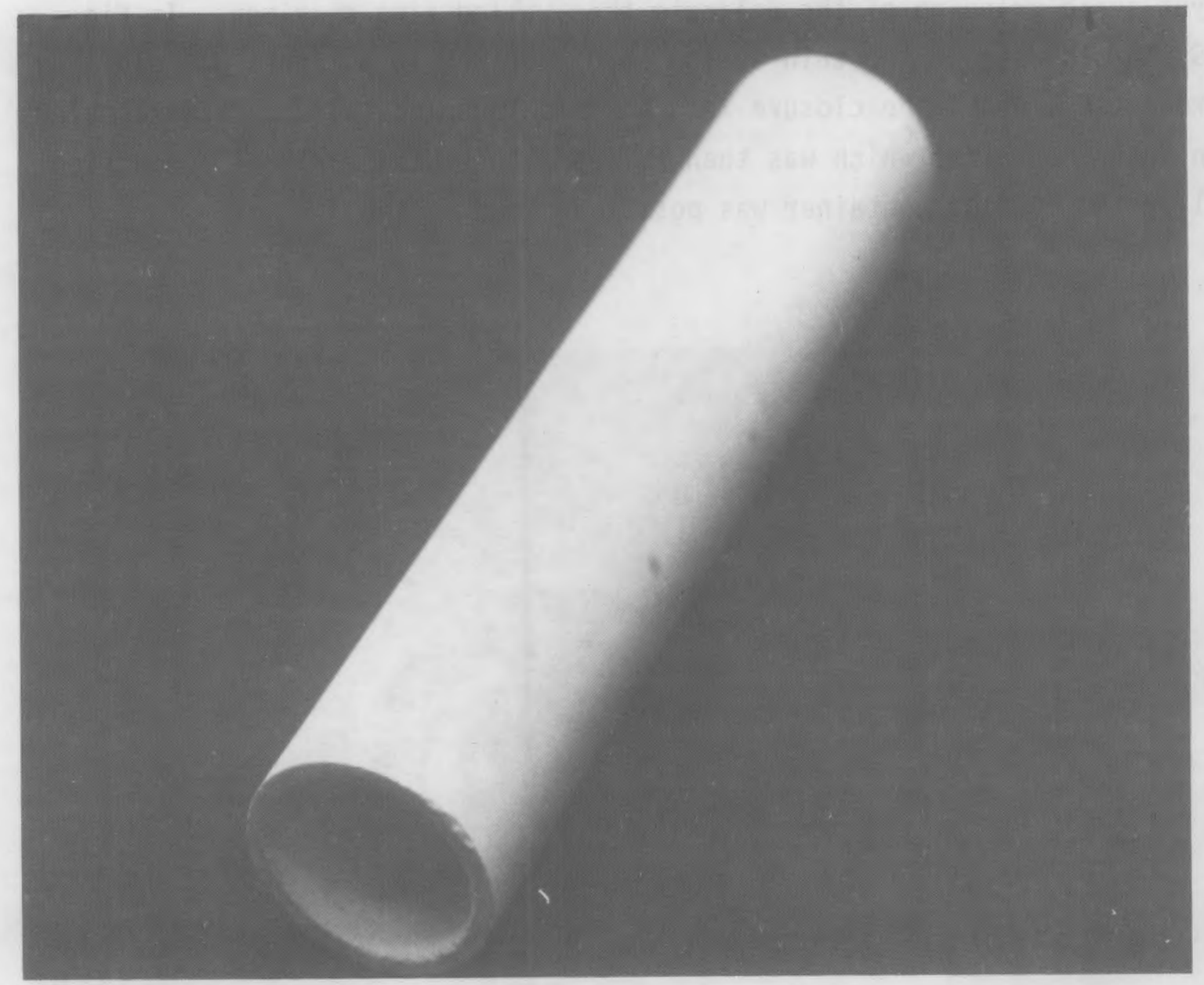

FIGURE 7. The Thin-walled $\mathrm{Li}_{2} \mathrm{O}$ Specimens for Ring Specimen Canister (Neg. $88102806-5 \mathrm{CN}$ )

localized areas of higher zirconium concentration caused a spotty discolorization of the specimen. These specimens were used because specimen's average zirconium concentration did not exceed the specification and because resynthesis of the powder could be done fast enough to meet the original delivery schedule.

The ring specimen was fabricated by Dr. 0. D. Slagle (PNL) from powder synthesized by Dr. R. B. Poeppel (ANL) from enriched lithium carbonate. The specimen fabrication was accomplished by isostatic pressing in a special mold so that the precise tolerances could be maintained on the external surface 
and yet avoid grinding of the delicate thin-walled ring specimen. In Figure 8 , the loading of the thin-walled $\mathrm{Li}_{2} \mathrm{O}$ specimen in an inert gas glovebox is presented. After the closure weld on this inner container, it was sealed in an outer container which was then filled with sodium for heat conduction. Finally, the outside container was positioned and sealed.

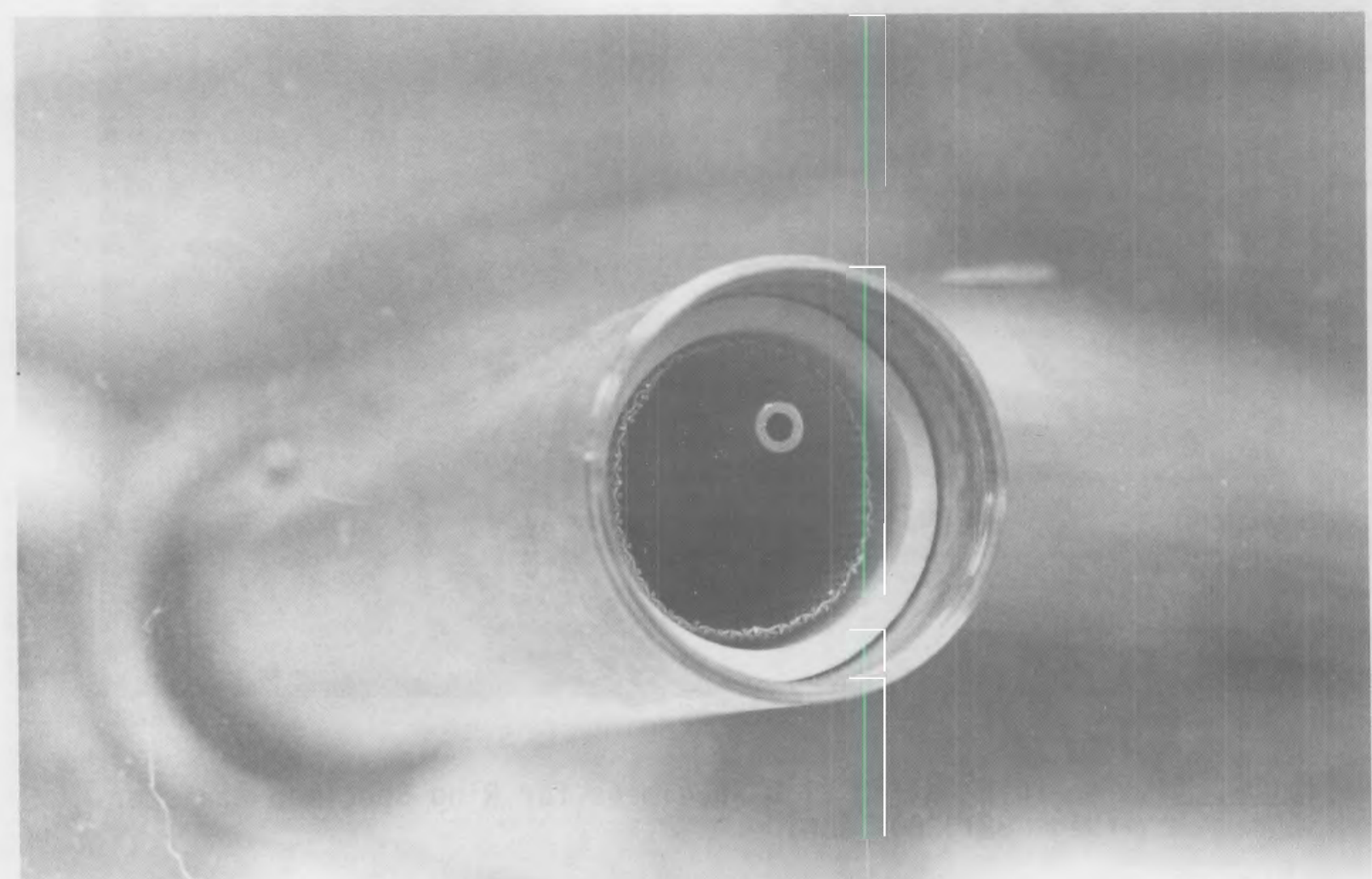

FIGURE 8. Loading of the Ring Specimen into the Inner Cladding in an Inert Gas Glovebox (Neg. $88112240-16 \mathrm{CN}$ ) 


\subsubsection{Solid Specimen}

The solid specimen canister was shown in Figure 3 . This canister was fabricated and attached to the MOTA stalk. To limit tritium loss during irradiation, it was necessary to not only barrier coat the outer stainless steel cladding of the capsule but also to insert a tungsten rhenium alloy sheath down the central thermocouple hole. Tungsten rhenium alloys possess a lower tritium permeation rate at high temperatures than many other materials. The flow of the sweep gas down the center of the $\mathrm{Li}_{2} \mathrm{O}$ pellets $\left(900^{\circ} \mathrm{C}\right)$ could result in significant LiOT transport so the gas was routed to the circumference of the pellets. If a gas gap was provided, a significant temperature increase would result. To avoid a temperature increase due to a gas gap between the solid pellet and canisters, a coarse, porous, nickel-powder layer was developed to provide adequate heat transfer and yet allow gas flow.

In Figure 9, the loading in an inert gas glovebox of the solid pellets into the outer cladding is shown. After the closure weld on the canister, it was attached to the MOTA stalk.

\subsubsection{Barrier coating}

Initial calculations indicated that tritium permeation through the cladding and tubing into the reactor's sodium coolant could result in significant errors in the tritium sweep gas measurement. A tritium permeation barrier (Figure 10) was applied to the stainless steel components to measure this error. Tritium permeation will also be a challenge for containment of tritium in actual fusion power plants. Calculations indicated that less than $1 \%$ of the tritium will be lost to the coolant in this experiment.

The coating applied to the stainless steel is a $0.01-\mathrm{cm}$ thick aluminized coating which was originally developed for the reduction of tritium permeation in liquid metal reactors. It was applied to the canister components and tubing by a U.S. vendor using a qualified process.

\subsubsection{Channeled Nickel Layer}

The solid pellet design required a porous metal region around the $\mathrm{Li}_{2} \mathrm{O}$ pellet to provide a gas flow path and high heat conduction. A process was 


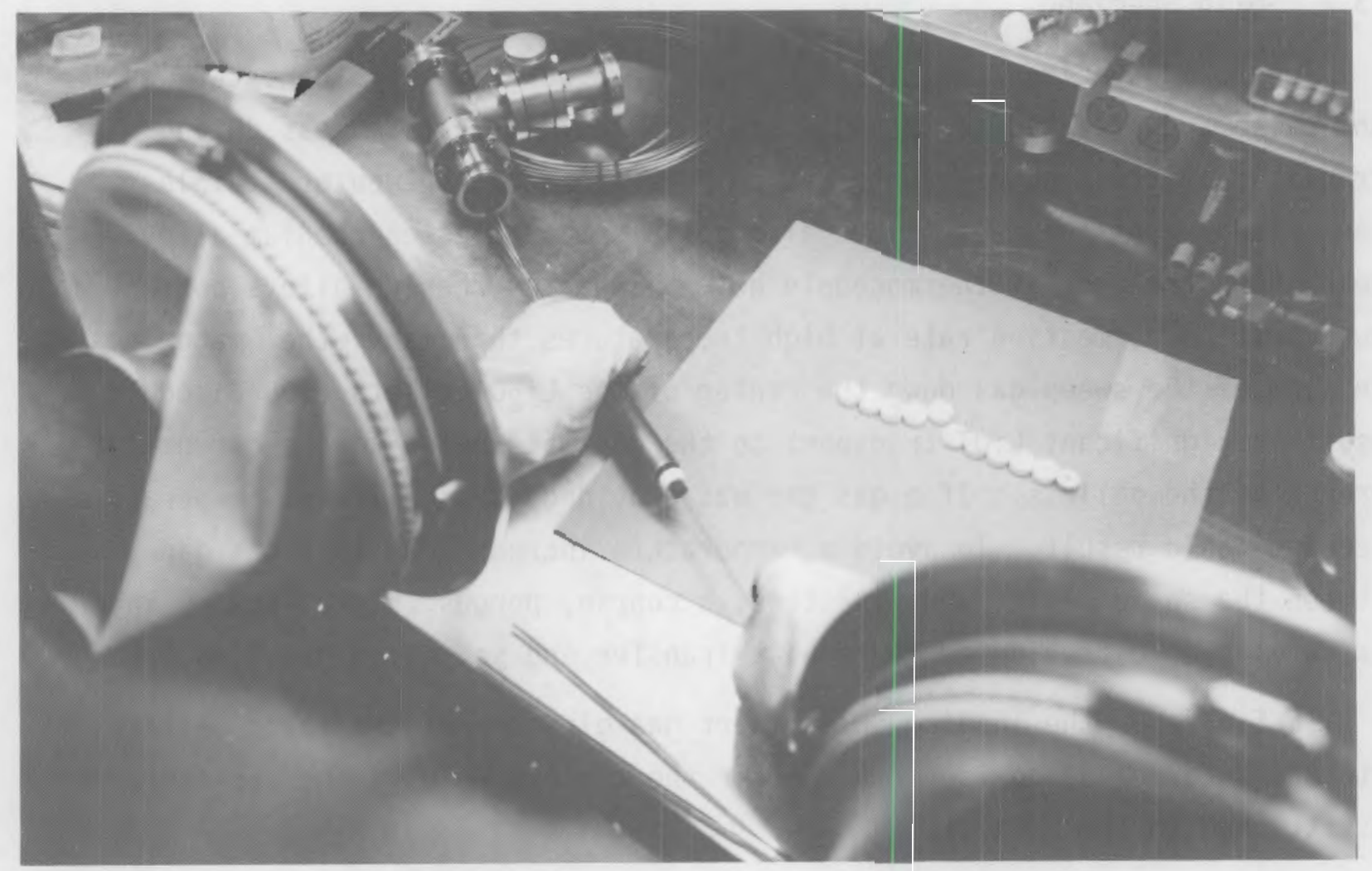

FIGURE 9. Loading of the Solid Pellets into the Solid Pellet Canister for BEATRIX-II, Cycle 11 (Neg. 88113015-2CN)
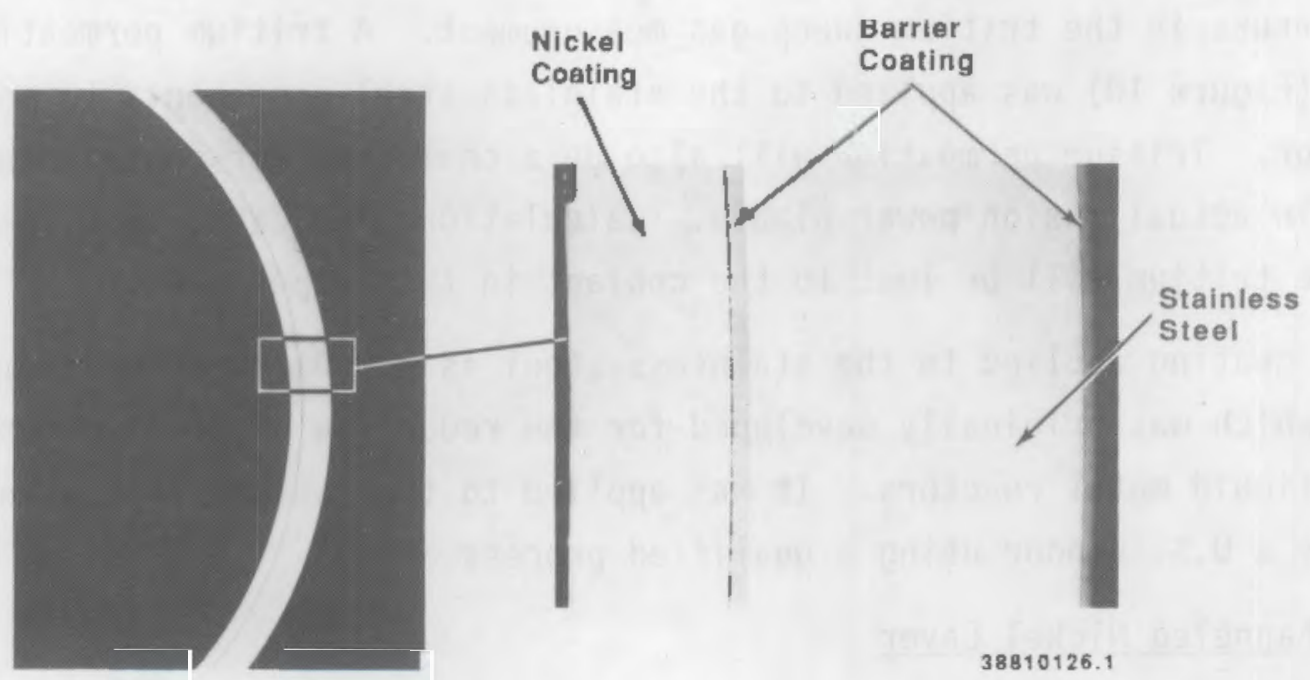

FIGURE 10. Micrograph of Tritium Barrier Coating Applied to Ring Specimen Canister (Neg. 88102113.2) 
developed which provided a large-grained nickel layer which is sintered to the external cladding. Originally, isostatic pressing was used to press the nickel powder in place but too dense a product was formed to allow adequate flow. By modifying of the forming process, a product of appropriate density was obtained as shown in Figure 11. Machining of the internal surface of the nickel layer allowed for a precision fit with the $\mathrm{Li}_{2} \mathrm{O}$ pellet. Nickel was used because of its compatibility with $\mathrm{Li}_{2} \mathrm{O}$.

A patent disclosure on the channelled nickel layer was written by Westinghouse Hanford and will be processed in accordance with ANNEX-III (see Appendix II).

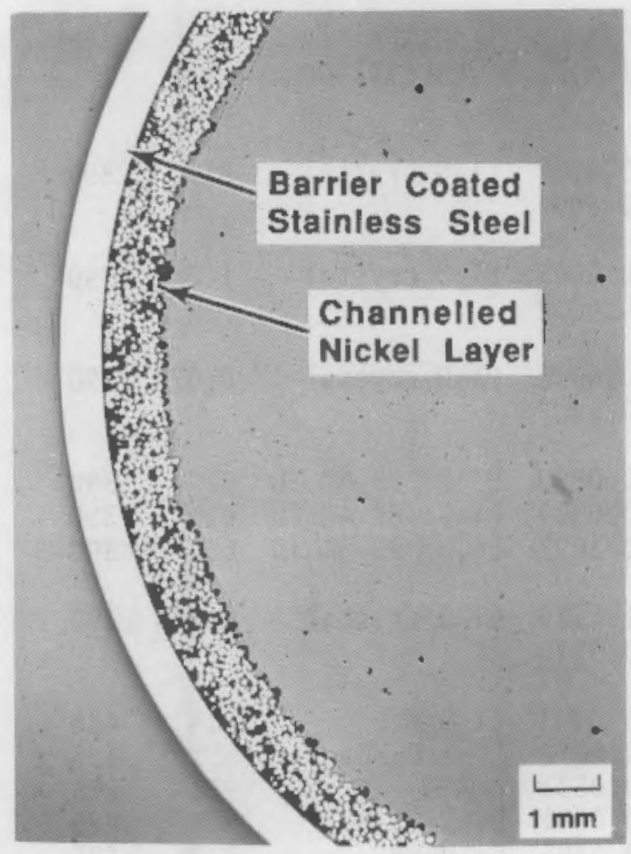

FIGURE 11. Micrograph of Channeled Nickel Layer on $\mathrm{Cl}$ adding of Solid Specimen (Neg. 88102113.1) 


\subsubsection{Nonvented Specimens}

In Table 7 the nonvented test matrix for BEATRIX-II, Phase I, is given. Specimens can be grouped according to the purpose of the testing. Specimens $\mathrm{B} 4, \mathrm{~B} 5$, and $\mathrm{B} 6$ are $\mathrm{Li}_{2} \mathrm{O}$ single crystals of varying enrichment which will be examined by ESR, TEM, and SEM in order to evaluate the build up of irradiation damage by both neutrons and transmutation products. Specimens in capsule $B 7$ will be used to measure the effect of irradiation on the thermal conductivity of $\mathrm{Li}_{2} \mathrm{O}$ during PIE. Specimens in capsule B8 will be returned to JAERI for isothermal tritium release measurements to be conducted.

\section{TABLE 7. BEATRIX-II Nonvented Capsule Matrix}

\begin{tabular}{|c|c|c|c|c|c|c|c|}
\hline $\begin{array}{l}\text { Capsule/ } \\
\text { Canister } \\
\end{array}$ & \multicolumn{3}{|c|}{$\begin{array}{l}\text { As Fab Dimensions } \\
\mathrm{OD}(\text { in) } \mathrm{L}(\text { in) WT (am) }\end{array}$} & $\begin{array}{c}\text { Material } \\
\text { Description }\end{array}$ & ENR & $\begin{array}{l}\text { Temp. } \\
(\underline{O} \underline{C})\end{array}$ & Purpose \\
\hline$/ 1 B$ & $\begin{array}{l}0.275 \\
0.275\end{array}$ & $\begin{array}{l}0.2214 \\
0.1761\end{array}$ & $\begin{array}{l}0.3917 \\
0.309\end{array}$ & $\mathrm{Li}_{2} \mathrm{O}$ crystal & $61 \%$ & 390 & ESR/Anneal/TEM/SEM \\
\hline / 18 & $\begin{array}{l}0.314 \\
0.314\end{array}$ & $\begin{array}{l}0.2089 \\
0.1735\end{array}$ & $\begin{array}{l}0.5045 \\
0.4012\end{array}$ & $\mathrm{Li}_{2} \mathrm{O}$ crystal & $1.8 \%$ & 390 & ESR/Anneal/TEM/SEM \\
\hline $5 / 1 B$ & $\begin{array}{l}0.314 \\
0.314\end{array}$ & $\begin{array}{l}0.2633 \\
0.1518\end{array}$ & $\begin{array}{l}0.6335 \\
0.3407\end{array}$ & $\mathrm{Li}_{2} \mathrm{O}$ crystal & $0.07 \%$ & 390 & ESR/Anneal/TEM/SEM \\
\hline $\begin{array}{l}\mathrm{B} 7 / \mathrm{D} \\
\mathrm{B} 7 \% 1 \mathrm{D} \\
\mathrm{B} 7 \% 1 \mathrm{D}\end{array}$ & $\begin{array}{l}0.3616 \\
0.36325 \\
0.3639\end{array}$ & $\begin{array}{l}0.03252 \\
0.03398 \\
0.03617\end{array}$ & $\begin{array}{l}0.0859 \\
0.0959 \\
0.1097\end{array}$ & $\begin{array}{l}\mathrm{Li}_{2} 0: 83.5 \% \text { TD } \\
\mathrm{Li}_{2} 0: 87.4 \% \text { TD } \\
\mathrm{Li}_{2} 0: 93.6 \% \text { TD }\end{array}$ & $\begin{array}{l}61 \% \\
61 \% \\
61 \%\end{array}$ & $\begin{array}{l}390 \\
390 \\
390\end{array}$ & $\begin{array}{l}\text { Thermal Diff. } \\
\text { Thermal Diff. } \\
\text { Thermal Diff. }\end{array}$ \\
\hline / 10 & $\begin{array}{l}0.314 \\
0.314\end{array}$ & $\begin{array}{l}0.7394 \\
0.3978\end{array}$ & $\begin{array}{l}1.8119 \\
0.9313\end{array}$ & $\mathrm{Li}_{2} \mathrm{O}$ crystal & $0.07 \%$ & 390 & Tritium Release \\
\hline $\begin{array}{l}\mathrm{B} 9 / 5 \mathrm{E} \\
\mathrm{B} 10 / 5 \mathrm{E} \\
\mathrm{B} 11 / 5 \mathrm{E} \\
\mathrm{B} 12 / 5 \mathrm{E} \\
\mathrm{B} 13 / 5 \mathrm{E} \\
\mathrm{B} 14 / 5 \mathrm{E} \\
\mathrm{B} 15 / 5 \mathrm{E} \\
\mathrm{B} 16 / 5 \mathrm{E} \\
\mathrm{B} 17 / 5 \mathrm{E} \\
\mathrm{B} 18 / 5 \mathrm{E} \\
\mathrm{B} 19 / 5 \mathrm{E} \\
\mathrm{B} 20 / 5 \mathrm{E} \\
\mathrm{B} 21 / 8 \mathrm{~B} \\
\mathrm{~B} 22 / 8 \mathrm{~B} \\
\mathrm{~B} 23 / 8 \mathrm{~B} \\
\mathrm{~B} 24 / 8 \mathrm{~B} \\
\mathrm{~B} 25 / 8 \mathrm{~B} \\
\mathrm{~B} 26 / 8 \mathrm{~B} \\
\mathrm{~B} 27 / 8 \mathrm{~B} \\
\mathrm{~B} 28 / 8 \mathrm{~B}\end{array}$ & $\begin{array}{l}0.1268 \\
0.1268 \\
0.127 \\
0.1276 \\
0.1278 \\
0.1273 \\
0.1271 \\
0.1288 \\
0.1269 \\
0.1272 \\
0.1266 \\
0.1262 \\
0.1273 \\
0.1271 \\
0.1269 \\
0.1282 \\
0.1263 \\
0.1271 \\
0.127 \\
0.1276\end{array}$ & $\begin{array}{l}0.12 \\
0.1185 \\
0.1174 \\
0.1191 \\
0.1184 \\
0.118 \\
0.1175 \\
0.1194 \\
0.1076 \\
0.1182 \\
0.1176 \\
0.1165 \\
0.116 \\
0.1186 \\
0.1175 \\
0.1139 \\
0.1183 \\
0.1168 \\
0.1187 \\
0.1155\end{array}$ & $\begin{array}{l}0.0404 \\
0.0872 \\
0.0531 \\
0.0481 \\
0.0385 \\
0.0885 \\
0.0548 \\
0.0483 \\
0.0346 \\
0.0882 \\
0.0547 \\
0.0451 \\
0.0389 \\
0.0872 \\
0.0529 \\
0.0458 \\
0.0378 \\
0.0877 \\
0.0551 \\
0.0473\end{array}$ & $\begin{array}{l}\mathrm{Li}_{2} \mathrm{O} / \mathrm{Be} \\
\mathrm{Li}_{2} \mathrm{ZrO}_{3} / \mathrm{Be} \\
\mathrm{LiAlO}_{2} / \mathrm{Be} \\
\mathrm{Li}_{4} \mathrm{SiO}_{4} / \mathrm{Be} \\
\mathrm{Li}_{2} \mathrm{O} / \mathrm{Be} \\
\mathrm{Li} \\
\mathrm{Li}_{2} \mathrm{ZrO}_{3} / \mathrm{Be} \\
\mathrm{Li}_{4} \mathrm{SiO}_{4} / \mathrm{Be} \\
\mathrm{Li}_{2} \mathrm{O}_{4} / \mathrm{Be} \\
\mathrm{Li}_{2} \mathrm{ZrO}_{3} / \mathrm{Be} \\
\mathrm{LiAlO}_{2} / \mathrm{Be} \\
\mathrm{Li}_{4} \mathrm{SiO}_{4} / \mathrm{Be} \\
\mathrm{Li}_{2} \mathrm{O} / \mathrm{Be} \\
\mathrm{Li}_{2} \mathrm{ZrO}_{3} / \mathrm{Be} \\
\mathrm{LiAlO}_{2} / \mathrm{Be} \\
\mathrm{Li}_{4} \mathrm{SiO}_{4} / \mathrm{Be} \\
\mathrm{Li}_{2} \mathrm{O} / \mathrm{Be} \\
\mathrm{Li}_{2} \mathrm{ZrO}_{3} / \mathrm{Be} \\
\mathrm{LiAlO}_{2} / \mathrm{Be} \\
\mathrm{Li}_{4} \mathrm{SiO}_{4} / \mathrm{Be}\end{array}$ & $\begin{array}{l}61 \% \\
69 \% \\
95 \% \\
68 \% \\
0.2 \% \\
2 \% \\
2 \% \\
2 \% \\
0.2 \% \\
2 \% \\
2 \% \\
2 \% \\
61 \% \\
69 \% \\
95 \% \\
68 \% \\
0.2 \% \\
2 \% \\
2 \% \\
2 \%\end{array}$ & $\begin{array}{l}425 \\
425 \\
425 \\
425 \\
425 \\
425 \\
425 \\
425 \\
425 \\
425 \\
425 \\
425 \\
440 \\
440 \\
440 \\
440 \\
440 \\
440 \\
440 \\
440\end{array}$ & $\begin{array}{l}\text { Compatibility } \\
\text { Compatibility } \\
\text { Compatibility } \\
\text { Compatibility } \\
\text { Compatibility } \\
\text { Compatibility } \\
\text { Compatibility } \\
\text { Compatibility } \\
\text { Compatibility } \\
\text { Compatibility } \\
\text { Compatibility } \\
\text { Compatibility } \\
\text { Compatibility } \\
\text { Compatibility } \\
\text { Compatibility } \\
\text { Compatibility } \\
\text { Compatibility } \\
\text { Compatibility } \\
\text { Compatibility } \\
\text { Compatibility }\end{array}$ \\
\hline
\end{tabular}


In capsules B9 through B28, disks of beryllium are layered between samples of $\mathrm{Li}_{2} \mathrm{O}, \mathrm{Li}_{4} \mathrm{SiO}_{4}, \mathrm{Li}_{2} \mathrm{ZrO}_{3}$, and $\mathrm{LiAlO}_{2}$. The purpose of these capsules is to evaluate the effect of irradiation and burn up on the compatibility of these lithium ceramics and beryllium. Burn up and neutron dose are evaluated separately by the variation of enrichment in these samples. Samples in canister $8 \mathrm{~B}$ are not expected to receive any significant neutron exposure or burnup and thus act as control samples.

Mechanical interaction test specimens were to have been irradiated in capsules B1, B2, and B3. However, it was not possible to arrive at a rational design in time for Cycle 11 . Consequently, the mechanical interaction test specimens are deferred to Cycle 12 irradiations. The purpose of these specimens was to identify the compressibility of the swelling of $\mathrm{Li}_{2} \mathrm{O}$ because it is anticipated that dilational creep can internally accommodate the unrestrained swelling previously observed. At first, the design of this specimen focused on almost isothermal specimens. But $\mathrm{Li}_{2} \mathrm{O}$ does swell significantly at the low temperatures which are appropriate for cladding. Higher temperatures which initiate swelling in $\mathrm{Li}_{2} \mathrm{O}$ are not appropriate for the cladding. A temperature gradient configuration such as the in-situ solid specimen is more appropriate. However, the high thermal expansion coefficient of $\mathrm{Li}_{2} \mathrm{O}$ makes it necessary to very precisely configure the specimen geometry in order to differentiate swelling effects from thermal expansion effects. Thermal control experiments in the laboratory may be required to distinguish, these effects.

\subsubsection{Self-Powered Neutron Detector}

The SPND chosen for the BEATRIX-II Phase I test uses rhodium as the sensitive element. This type of SPND is similar to the design used in earlier instrumented tests in the FFTF. The SPND will provide real time information on the local neutron flux near the vented canisters. For the Phase I test, the SPND has been mounted next to the ring specimen geometry canister. Instrumentation for the SPND will be mounted in the FFTF head compartment which is adjacent to the MOTA instrumentation penetrations through the reactor vessel. 


\subsubsection{Instrument and Control System}

The I\&C for the MOTA system will monitor the temperatures in the instrumented canisters and provide temperature control for the gas-gapped canisters, i.e. the ring specimen and some of the nonvented samples. Figure 12 shows the completed system ready for shipment to the FFTF site. The system is completely automated with both a primary subsystem and a secondary subsystem which is needed to assure uninterrupted operation. The computer automatically adjusts gas mixtures for each temperature. This system was operated in a simulation mode for 3 weeks before being shipped to FFTF for installation.

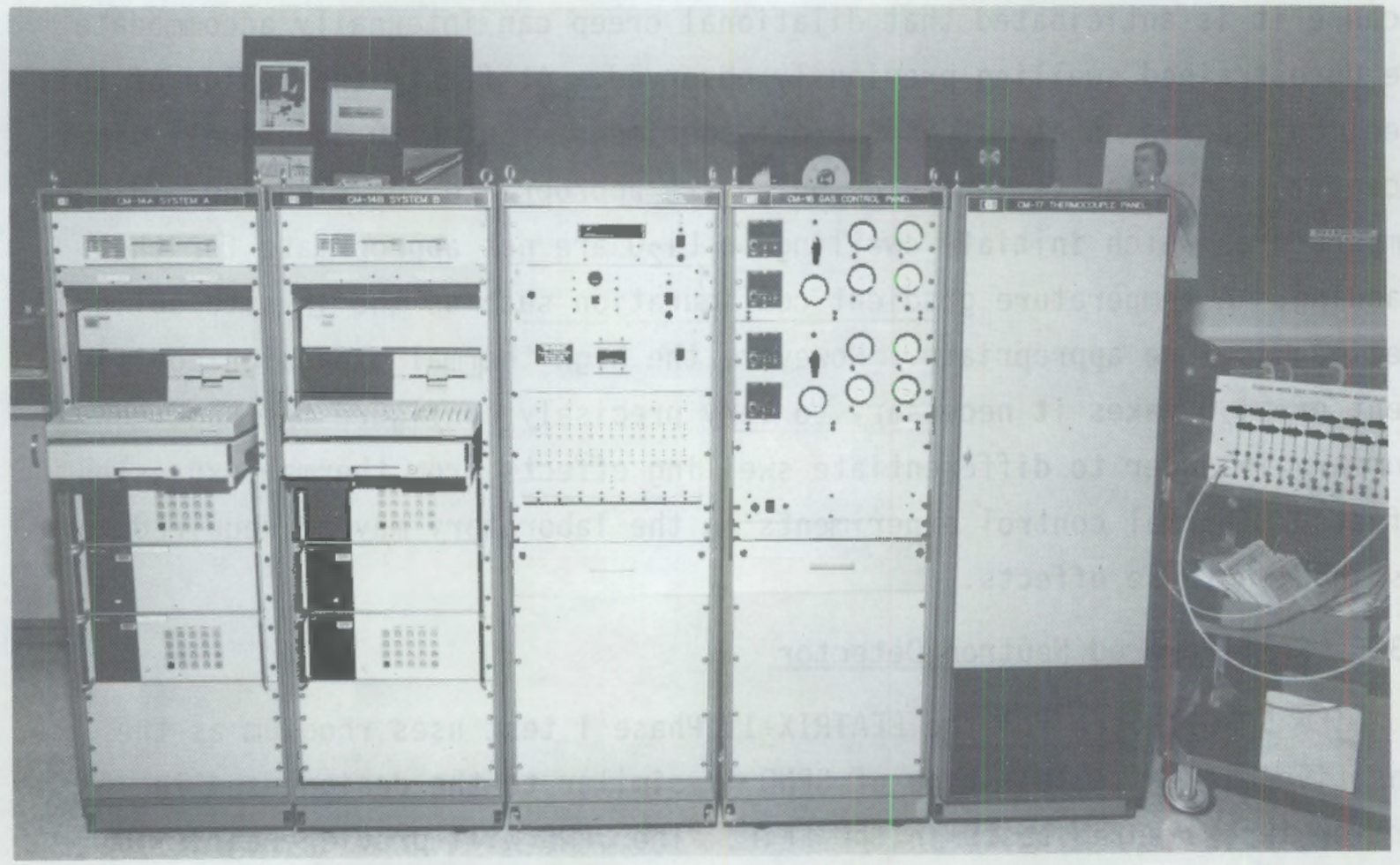

FIGURE 12. The Instrument and Control System (I\&C) Before Shipment to FFTF (Neg. $88090660-3 \mathrm{CN}$ ) 


\subsubsection{MOTA Assembly}

Beyond the fabrication of the two BEATRIX-II in-situ recovery canisters, it is necessary to attach all of the other canisters to the central stalk with full instrumentation and to provide appropriate quality assurance. The fabrication and assembly of the entire fusion MOTA assembly is approximately $50 \%$ complete. Figure 13 shows the present status of the fusion MOTA irradiation vehicle assembly. All canister components have been fabricated and assembled into canisters. The test train which holds the canisters has been assembled and all canisters have been mounted to the test train. Assembly has started on the upper portions of the irradiation vehicle.

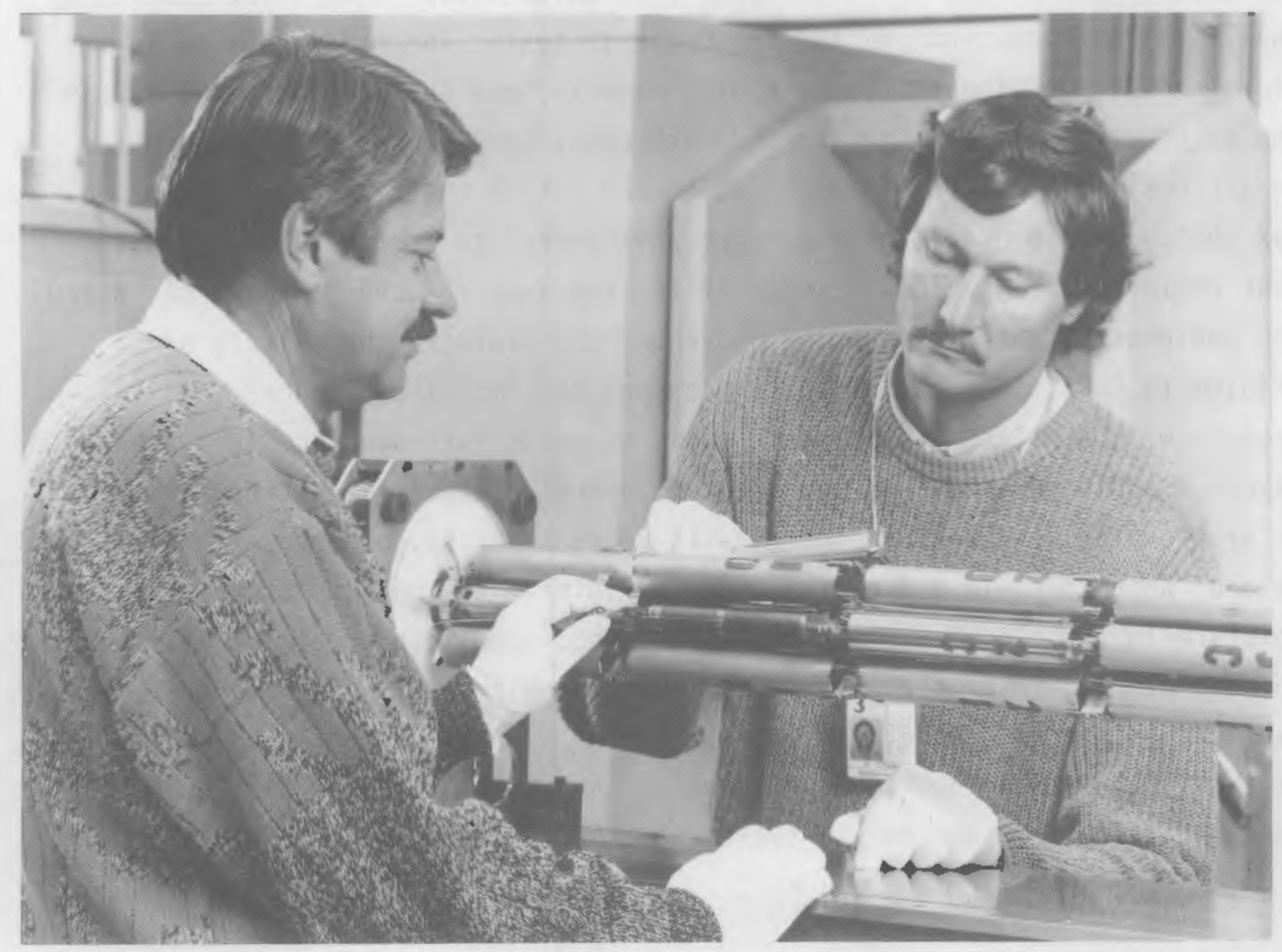

FIGURE 13. Fusion MOTA Test Vehicle Fabrication Status During December 1988 (Neg. 89010336-6CN) 


\subsection{IRITIUM HANDLING SYSTEM}

The tritium handling system consists of a gas analysis system and a tritium removal system contained within a glovebox. The glovebox will be installed on the main operating deck of FFTF.

\subsubsection{Glovebox Modifications}

The glovebox provides the secondary containment for the tritiated sweep gas as it flows through the gas Analysis and tritium removal systems. The glovebox is shown in Figure 14 before significant modifications had occurred. The glovebox inner dimensions are $7 \mathrm{ft}$ (wide) $\times 9 \mathrm{ft}$. (high) $\times 2.5 \mathrm{ft}$. (deep). This glovebox provides sufficient space for the equipment to be used in the Cycle 11 test and has some additional room which could be used for additional analytical systems required for the cycle 12 test. The modifications to the glovebox included the fabrication of a base to hold the glovebox, the machining of penetrations for the gas and instrument leads, and the attachment of an airlock for transfer of equipment in and out of the glovebox. The glovebox system will provide the necessary environment to assure accurate instrument performance, preclude release of tritium into reactor containment, allow for equipment transfers into the glovebox, and minimize the release of tritium to CAPS, the reactor gas processing system. The glovebox will operate with a nitrogen atmosphere so as to avoid instrument calibration issues associated with the operation of instrumentation in other gases such as argon. The glovebox atmosphere will be continuously purged to CAPS at a rate of approximately $0.3 \mathrm{cu} \mathrm{ft./min}$. to minimize the buildup of tritium and moisture in the glovebox. The glovebox is equipped with a refrigeration unit to maintain the instrument sensor temperatures within it. In Figure 15, the fabrication status of the glovebox during the Operating Agent's on-site review in early December 1988 is shown. Since to that review, all components except for the tritium removal system have been placed into the glovebox.

\subsubsection{Glovebox Cleanup System}

The glovebox is equipped with a glovebox cleanup system. This system consists of a molecular sieve to remove moisture, a metal getter system (SAES-ST198) to remove the tritiated gas, and a pump to circulate the glovebox atmosphere through the cleanup system. The system is sized to reduce the 


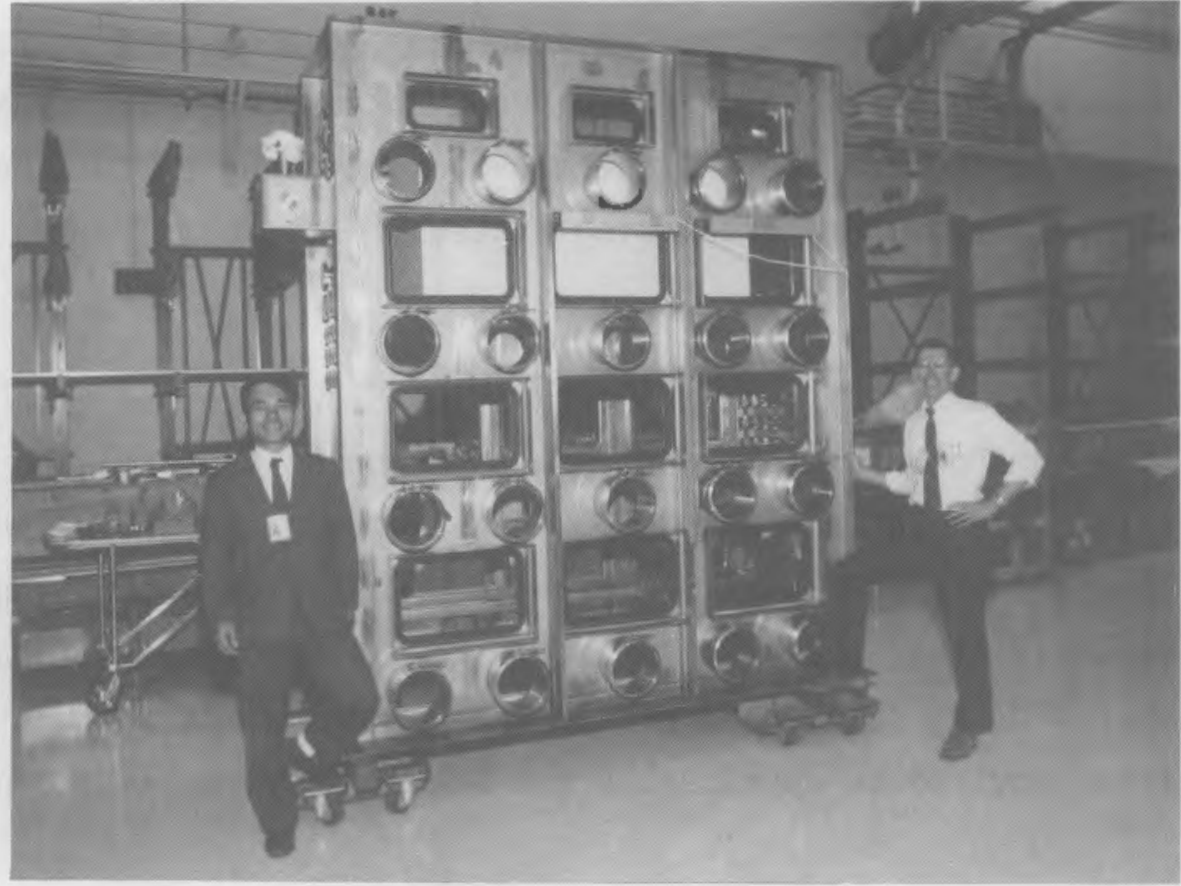

FIGURE 14. Tritium Glovebox Before Being Modified for BEATRIX-II (Neg. 88092966-5CN)

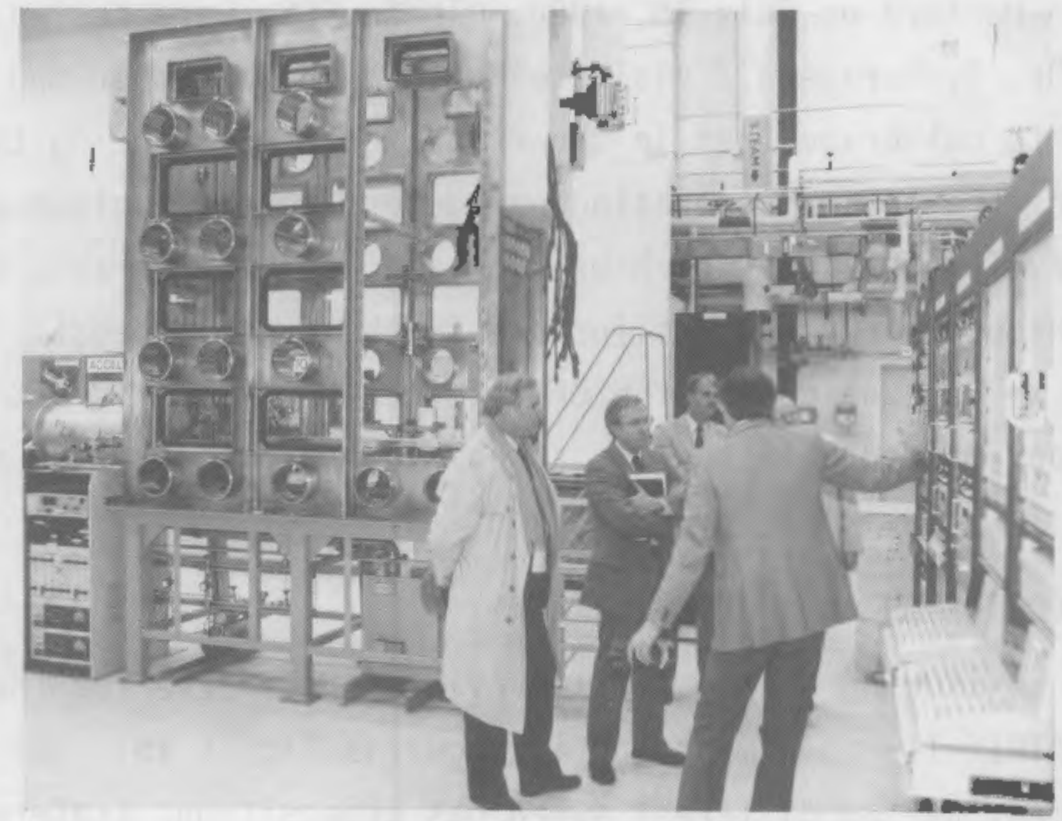

FIGURE 15. Tritium Handling System Including Glovebox and Data Acquisition System During Operating Agent On-site Review. During Early December 1988 (Neg. 88120736-22CN) 
tritium concentrations in the glovebox atmosphere to levels below $1 \mathrm{mCi} / \mathrm{m}^{3}$. (Hydrogen must be present or introduced into the glovebox atmosphere to reach these tritium levels.) Cleanup of the glovebox atmosphere could take approximately $72 \mathrm{hrs}$. During this period the glovebox atmosphere would be isolated from the FFTF cell atmosphere processing system.

\subsubsection{Gas Analysis System}

The gas analysis system provides a parallel flow path for each canister's sweep gas in order to continuously measure both the total and tritium gas releases from each vented canister. The valving pattern for the analysis system for one canister is shown in Figure 16. During the operation of the test these valves will be operated only to take gas samples (calibration of the ion chambers) or to remove and repair any sensors which malfunction. The instrumentation required to operate the gas analysis system is shown in Figure 17 .

\subsubsection{Ceramic Electrolysis Cells}

JAERI provided two CECS for the reduction of any moisture in the gas streams into tritium/hydrogen and oxygen gases. The two CECS were received by Westinghouse Hanford on JuTy 18, 1988. These CECS were tested and calibrated during Dr. T. Kurasawa's visit to Hanford in September and October. The setup used to calibrate them is shown in Figure 18. During their testing and calibration, the optimum operating parameters were established. One of the CECs had developed a leak which was located near the ceramic-to-metal seal. JAERI shipped a replacement for use in the Cycle 11 test. 8ased on these results, we can anticipate the CECs to be approximately $95 \%$ efficient in converting any moisture in the gas stream to hydrogen/tritium and oxygen gas.

\subsubsection{Inlet Monitoring and Control System}

The inlet monitoring system (IMS) provides the source for the sweep gas used in the BEATRIX-II experiment and is shown in Figure 19. The design allows for as many as two different sweep gas compositions (reference and alternate) to be used simultaneously (one in each vented canister). The IMS also permits the oxygen concentration in the sweep gas to be checked before 


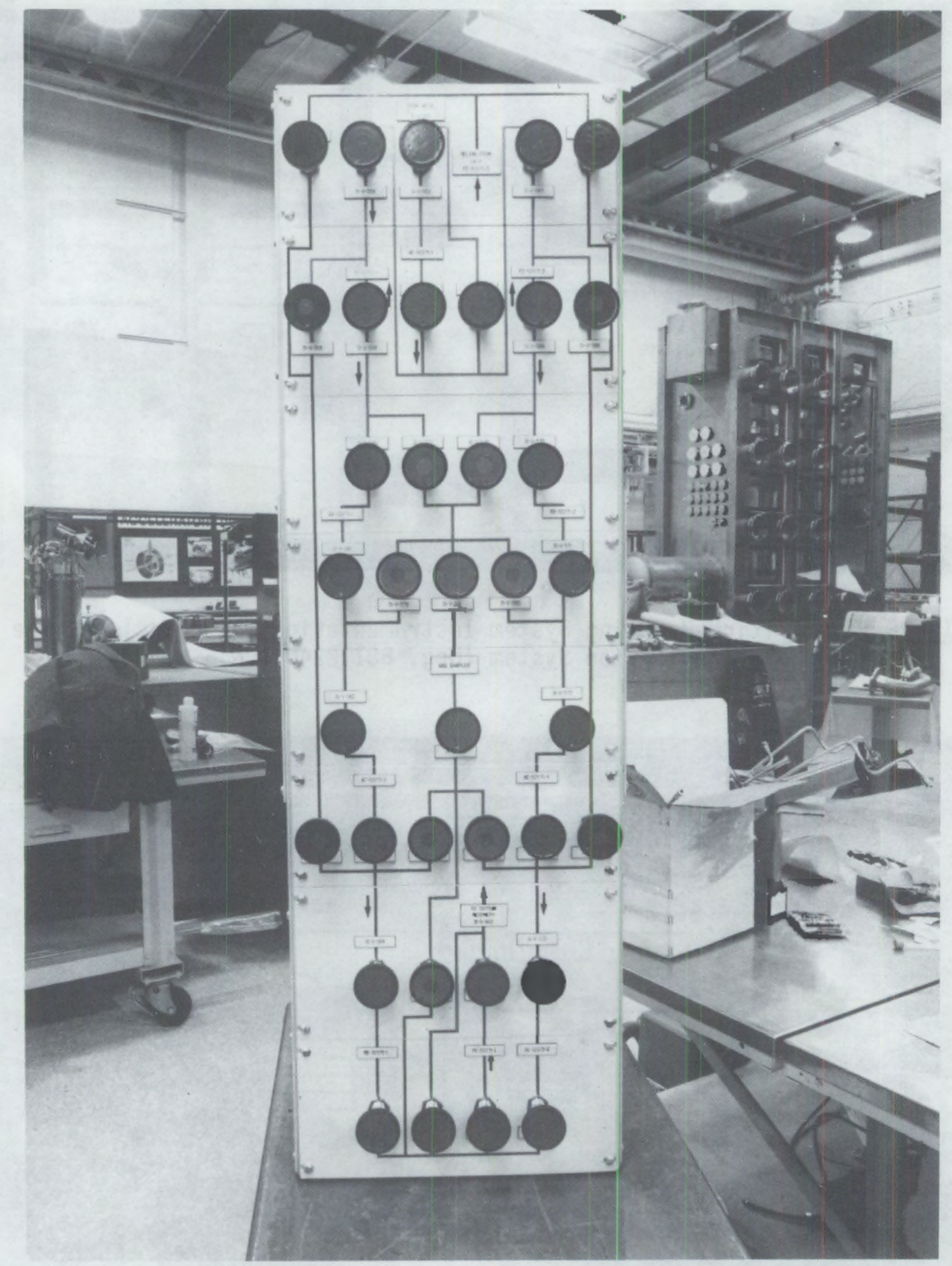

FIGURE 16. Valving Pattern for the Gas Analysis System of BEATRIX-II (Neg. $88112240-4 \mathrm{CN}$ ) 


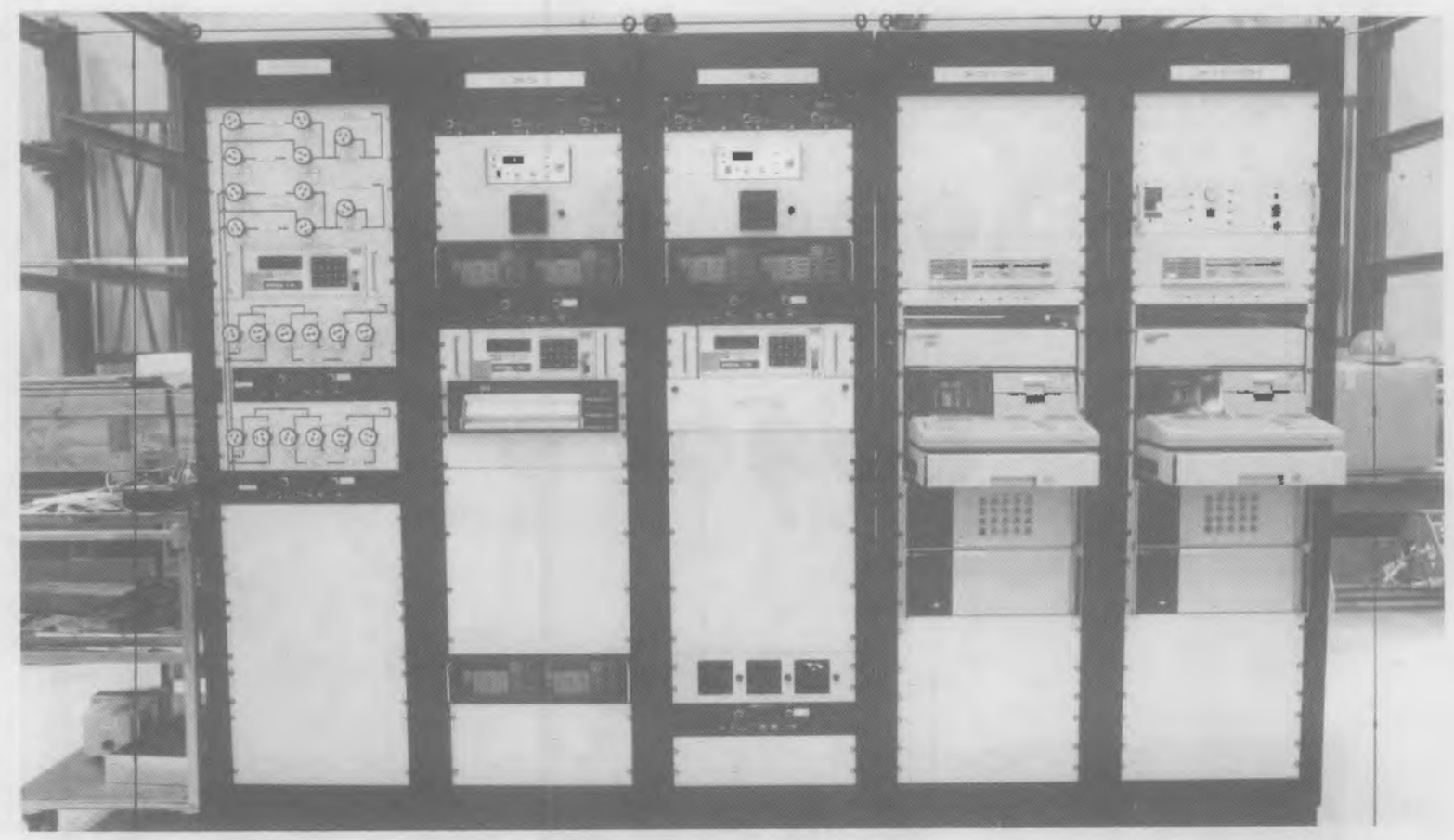

FIGURE 17. Tritium Handling System Instrumentation Which Includes the Data Acquisition System (Neg. 88112240-3CN)

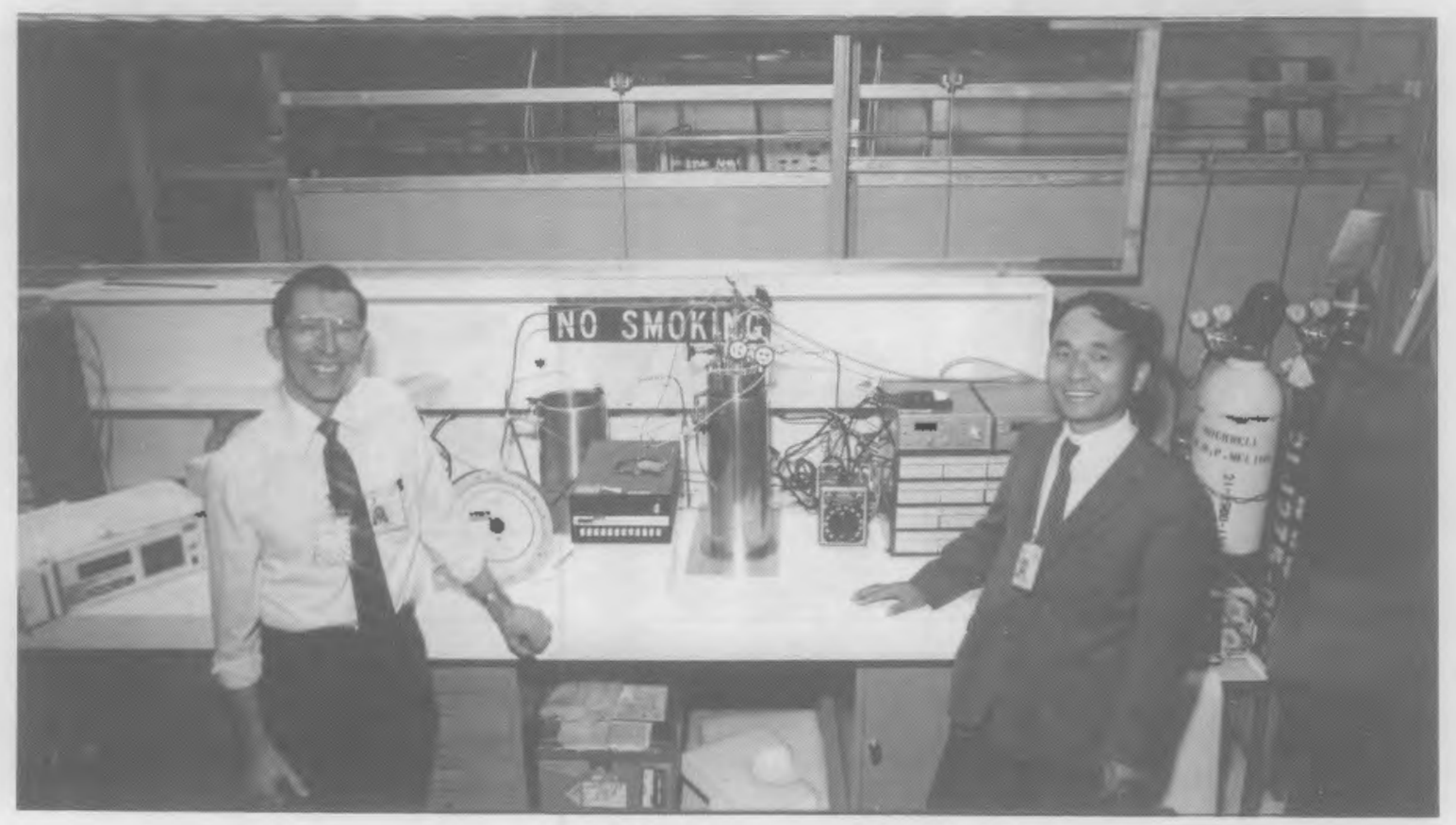

FIGURE 18. Testing of BEATRIX-II's Ceramic Electrolysis Cells from JAERI in October 1988 (Neg. 88090966-3CN) 


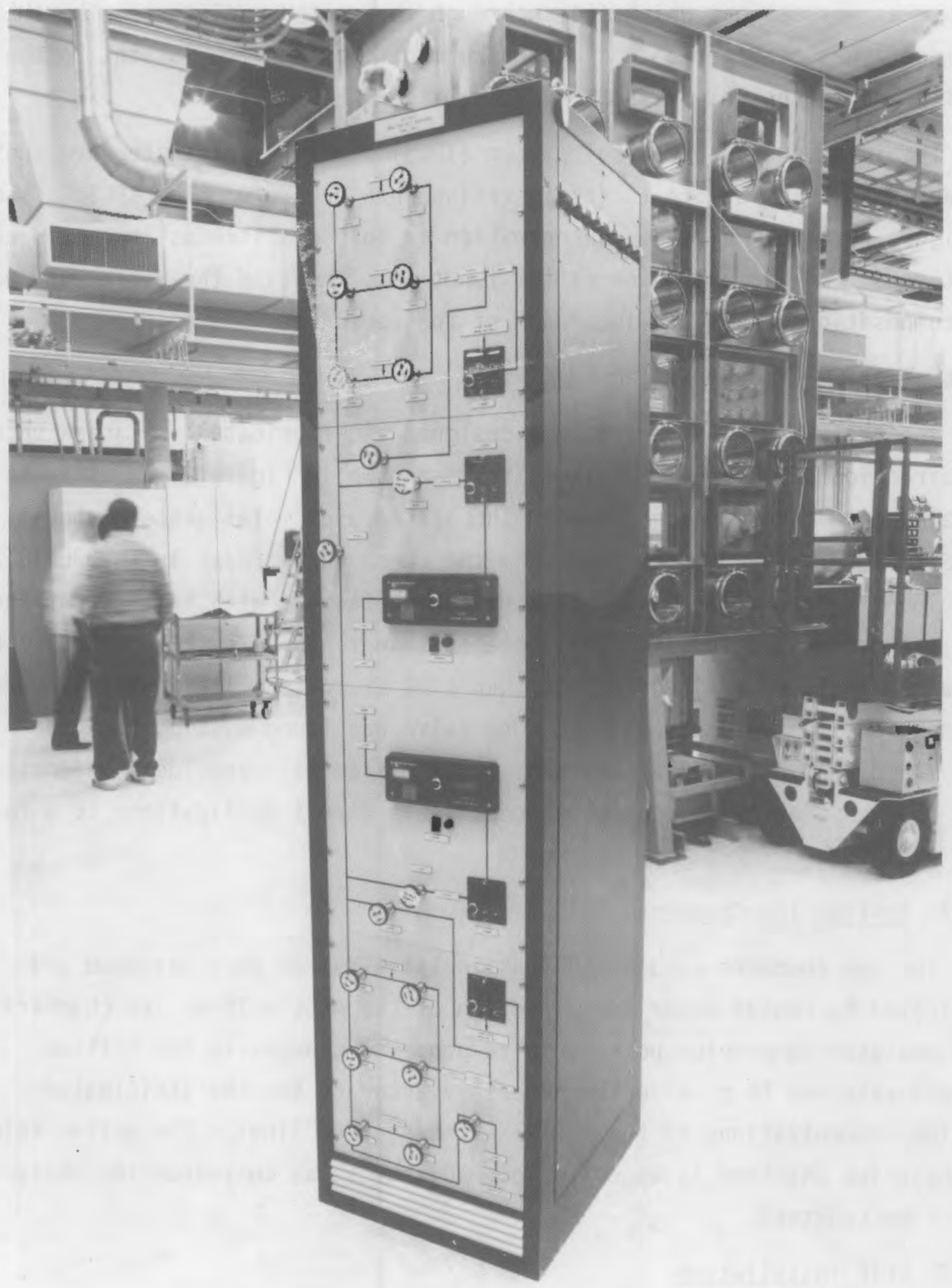

FIGURE 19. Inlet Monitoring System in December 1988 (Neg. 88112240-2CN) 
its use as a sweep gas which flows through the vented canisters. The IMS provides a gas purifier on each gas stream before the flow is sent to the inlet pressure control system.

The inlet pressure control system (IPCS) provides inlet pressure control of each gas stream before to its insertion into the MOTA. The IPCS is shown in Figure 20. The moisture concentration in both gas streams is continuously monitored. The IPCS also serves the function of routing the different sweep gas compositions available into each of the vented canisters.

\subsubsection{Iritium Removal System}

The tritium removal system was designed and fabricated in Canada under the direction of the AECL. This system is shown in Figure 21 as it is being unloaded from the shipping crates. The system uses metal getter material (SAES 707) to remove the tritium from the sweep gas streams in the BEATRIX-II experiment. Dr. Miller measured detritiation factors with tritium for the SAES 707 getter and found factors greater than required by FFTF (2500). Each getter bed will be limited to less than $1000 \mathrm{Ci}$ to facilitate burial and/or shipment and to avoid saturation. One valve was found missing from the system and was installed at Hanford. This system will provide a demonstration of sweep gas technology which could have direct applications to a fusion fuel cycle.

\subsubsection{Tritium Ion Chambers}

The ion chambers used in the gas analysis system were designed and fabricated by Canada under the direction of the AECL. These ion chambers were designed to provide both rapid response to changes in the tritium release rate and to provide the necessary accuracy for the anticipated tritium concentrations in the BEATRIX-II sweep gas lines. The active volume in these ion chambers is approximately $100 \mathrm{~cm}^{3}$ so as to reduce the measurement time constant.

\subsubsection{FFTF Installation}

Progress has been made during the last year to ready the FFTF site for the installation of the BEATRIX-II experiment's glovebox. An area on the main entrance level of the reactor was identified and unused equipment 


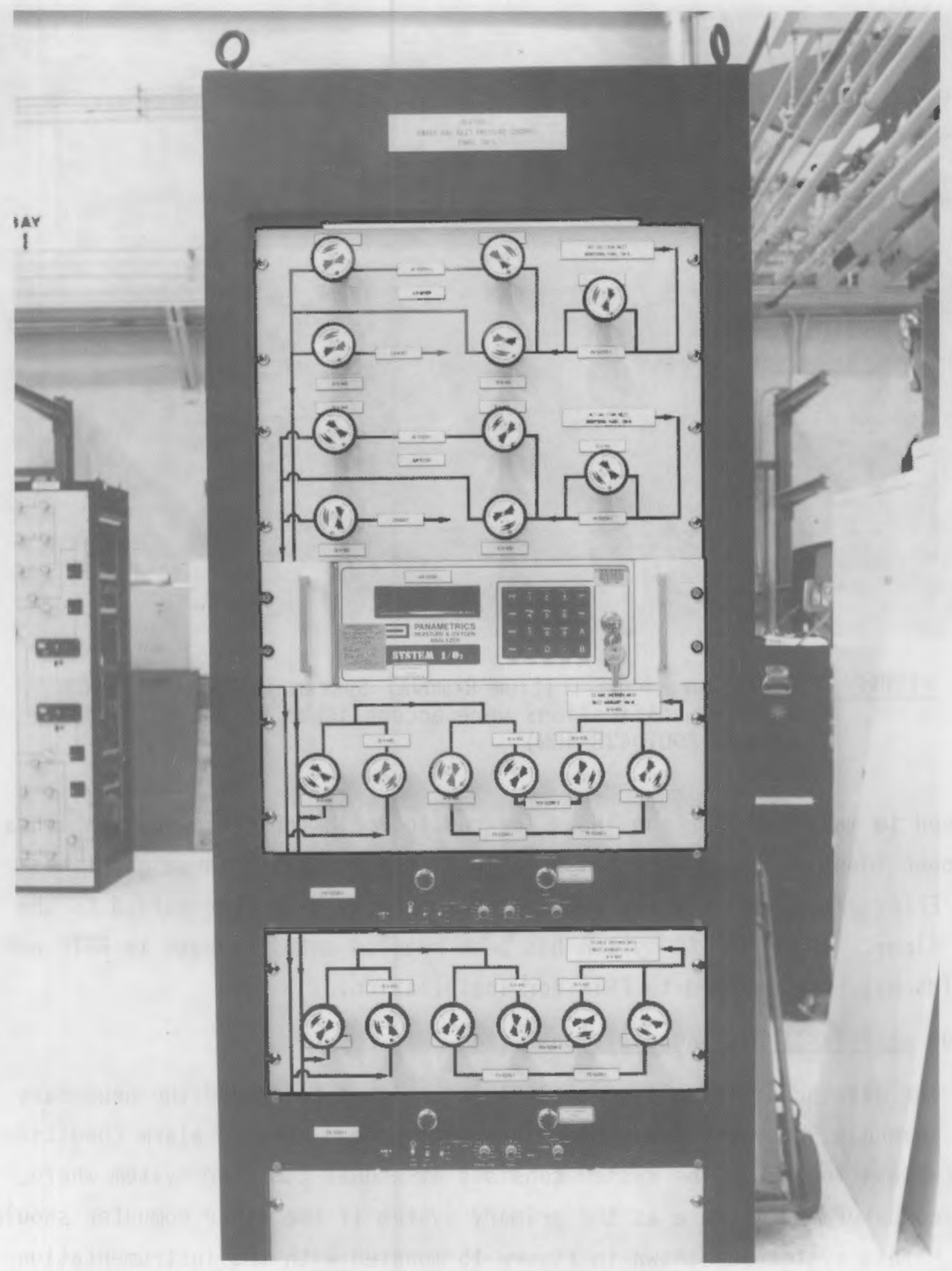

FIGURE 20. Inlet Pressure Control System in December 1988 (Neg. 88101939-1CN) 


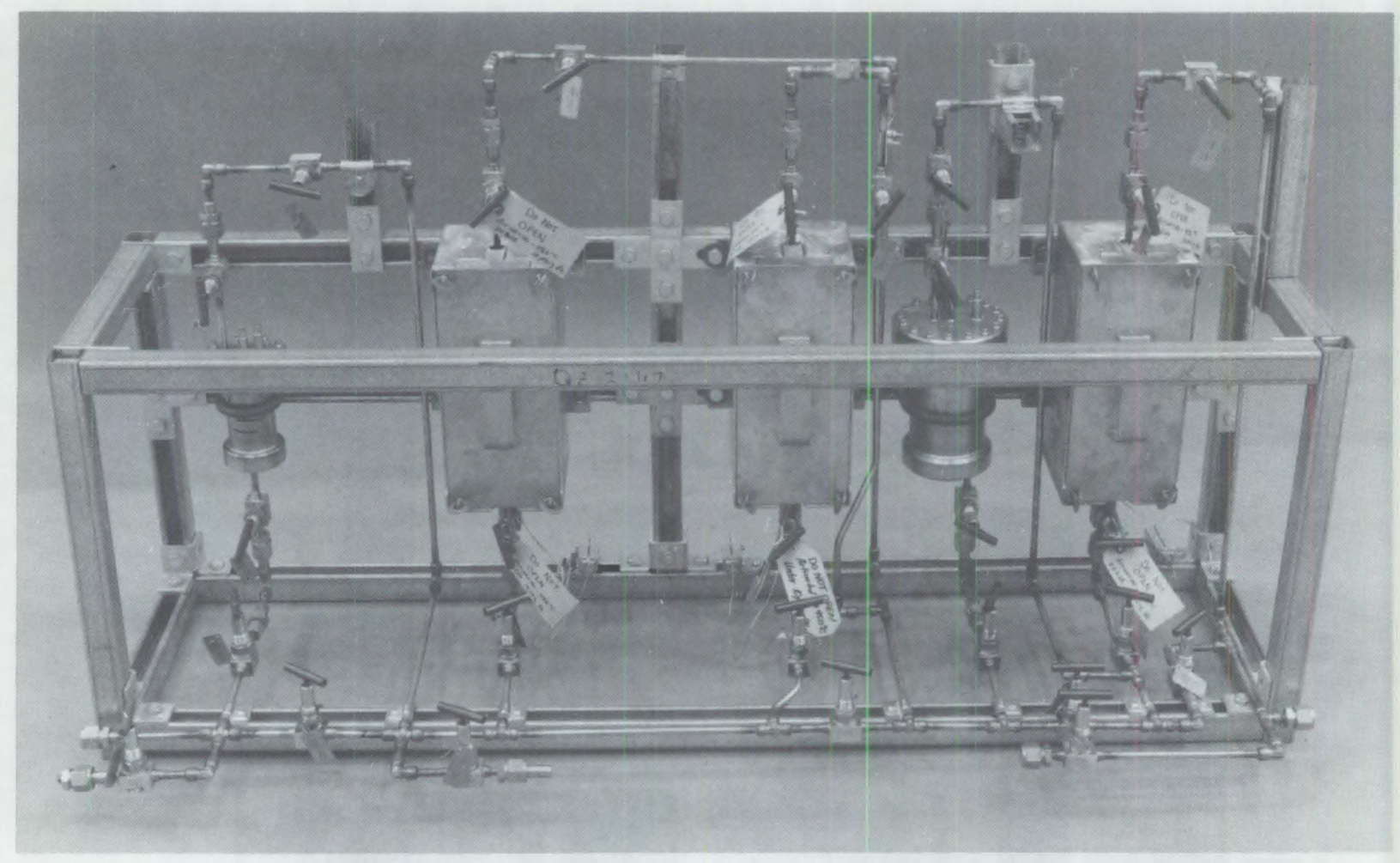

FIGURE 21. Photograph of Tritium Removal System in November 1988. Valve modifications were accomplished in December 1988. (Neg. 89010438-4CN)

removed to make room for the THS. The routing path for the sweep gas lines has been identified and work has been initiated in laying these gas lines into FFTF. The bases for the THS instrument racks have been welded to the FFTF floor. The MOTA I\&C system has been mounted onto its base in FFTF and the IMS has been shipped to FFTF for installation.

\subsubsection{BEATRIX-II Data Acquisition System}

The data acquisition system (DAS) is designed to record the necessary data channels, provide operational information, and provide alarm condition indications to FFTF. The system consists of a dual computer system where each computer can operate as the primary system if the other computer should fail. This system was shown in Figure 15 mounted with the instrumentation for the gas analysis system. The DAS has the capability of recording up to 60 channels of data every 10 seconds. This capability is readily expandable to over 300 channels if required for Cycle 12. In performing its operational 
to over 300 channels if required for Cycle 12. In performing its operational function, it provides the operator the capability of monitoring the various channels coming into the computer, and it keeps a running $\log$ on the accumulated tritium in each of the various trapping sites for tritium within the sweep gas system. Should an abnormal condition arise, the computer activates an alarm in the control room in FFTF to indicate the system is not performing as designed.

\subsection{DATA ANALYSIS}

Data from the BEATRIX-II experiment will be compiled at FFTF on a Hewlett Packard computer, i.e the Data Acquisition System. It will then be transferred to an IBM personal computer at PNL where it will be broken into run files and distributed by either disk or MFE network to the working group members for analysis. A test data set was sent to JAERI to confirm the compatibility of these systems with JAERI hardware. It is anticipated that the participants will individually analyze the resulting data and then meet to collaborate on the conclusions to be made from these results.

Data Channels for BEATRIX-II are given in Table 8. Data is broken chronologically into runs as changes are made to the operating environment. In Table 9, a projection of parameter changes are presented for the first 100 EFPD of operation. Parameters to be changed include the temperature, flow rate, and sweep gas composition. Because each run will be continued until steady-state tritium release is observed, an exact time based schedule cannot be arrived at before irradiation. Flexibility in establishing the next run is required to take advantage of the results obtained. FFTF is expected to run at full power for three 100 EFPD periods except for the initial startup sequence, power coefficient testing (down to $75 \%$ power), and reactivity feedback testing (down to $75 \%$ power). The latter two events are short in duration, i.e., less than one day.

At the beginning and end of each $100 \mathrm{FFPD}$ period (runs 11A, 11B, and 11C) sampling chambers will be removed from the gas analysis system and analyzed in order to calibrate the ionization chambers. 
TABLE 8. Experimenter BEATRIX-II Channels

Subject

Measurement

Location Channel No.

BEATRIX-II Analysis System Data Channels

1.0 General

Reactor
Reactor
Reference Gas
Alternate Gas
Ring Sweep Gas
Solid Sweep Gas

2.0 Ring Specimen

2.1 General

Sweep Gas

Sweep Gas

Sweep Gas

$\mathrm{Li}_{2} \mathrm{O}$

$\mathrm{Li} 2 \mathrm{O}$

$\mathrm{Li} 20$

2.2 CEC Line

Sweep Gas

Sweep Gas

2.3 Mol Sieve Line

Sweep Gas

Sweep Gas
Time

Flux (SPND)

Moisture

Moisture

Pressure

Pressure
PST

Level I

Inlet

Inlet

Inlet

Inlet
0
35
3
4
1
2

Pressure

Flow Rate

Moisture

Temperature

Temperature \#1

Temperature \#2

Flow Rate

Tritium Conc

Flow Rate

Tritium Conc
Outlet

Outlet

Outlet

OD

ID

ID

CEC Line

CEC Line

MS Line

MS Line
11

17

5

47

48

49

18

1001

19

1002

3.0 Solid Specimen

3.1 General

Sweep Gas

Sweep Gas

Sweep Gas

$\mathrm{Li}_{2} \mathrm{O}$

$\mathrm{Li}_{2} \mathrm{O}$

$\mathrm{Li} 2 \mathrm{O}$

3.2 CEC Line

Sweep Gas

Sweep Gas

3.3 Mol Sieve Line

Sweep Gas

Sweep Gas

Pressure

Moisture

Flow Rate

Temperature

Temperature \#1

Temperature \#2

Flow Rate

Tritium Conc

Flow Rate

Tritium Conc

Outlet

Outlet

12

Outlet

8

OD

ID

ID

CEC Line 21

CEC Line $\quad 1003$

MS Line 22

MS Line $\quad 1004$

4.0 Tritium Handling System Parameters

Sweep Gas

Sweep Gas

Getter Bed
Pressure

Pressure

Temperature
Exit Solid

System

Exit Ring

System

TRS \#1
23

24

37 
TABLE 8. (contd)

Subject

Getter Bed

Getter Bed

Exhaust Gas

Exhaust Gas

Exhaust Gas

Ring Specimen

Ring Specimen

Sweep Gas

Sweep Gas

Sweep Gas

Sweep Gas

Sweep Gas

Sweep Gas

Sweep Gas

Sweep Gas

Solid Specimen

Solid Specimen

Glove Box

Glove Box

Glove Box

Glove Box

G1ove Box

Glove Box

Glove Box

Glove Box

Glove Box

Glove Box

GTove Box

Glove Box

Glove Box
Measurement

Temperature

Temperature

Tritium

Tritium

Pressure

Temperature

Temperature

CEC Potential

CEC Current

Moisture

CEC Potential

CEC Current

Moisture

Moisture

Moisture

Temperature

Temperature

Pressuredifferential

Pressuredifferential

Pressure-absolute Argon Flow

Tritium

Tritium

Tritium

Tritium

Moisture

Temperature

Temperature

Temperature

Temperature
Location Channel No.

TRS \#2 38

TRS \#3 39

Outlet TRS 1006

Inlet TRS $\quad 1005$

Outlet TRS 25

CEC 50

CEC 51

Ring Specimen 13

Ring Specimen 14

Ring Specimen

After CEC 6

Solid Specimen 15

Solid Specimen 16

Solid Specimen

After CEC 9

Solid Specimen After MS 10

Ring Specimen After MS 7

CEC $\quad 52$

CEC 53

Control 26

Measurement 27

Measurement 28

Inlet 29

Monitor 30

Range $0 \quad 31$

Range $1 \quad 32$

Range $2 \quad 33$

Monitor 34

Getter Bed $\quad 40$

Inlet 41

Outlet $\quad 42$

Static $\quad 43$ 
TABLE 9. BEATRIX-II, Cycle 11, Preliminary Test Scenario

\begin{tabular}{|c|c|c|c|c|c|}
\hline Run ID & Power & $\begin{array}{l}\text { Ring Specimen } \\
\text { Temp }\left({ }^{\circ} \mathrm{C}\right) \\
\end{array}$ & $\begin{array}{l}\text { Ring Specimen } \\
\text { Gas } / F 10 w(\mathrm{cc} / \mathrm{m})\end{array}$ & $\begin{array}{l}\text { Solid Specimen } \\
\text { Gas/Flow }(\mathrm{cc} / \mathrm{m})\end{array}$ & Comments \\
\hline $\begin{array}{l}11-1 a \\
11-1\end{array}$ & $\begin{array}{l}0 \text { to } 100 \\
100\end{array}$ & $\begin{array}{c}450 / 575 \\
625\end{array}$ & $\begin{array}{l}0.1 \% \mathrm{H}_{2} / 100 \\
0.1 \% \mathrm{H}_{2} / 100\end{array}$ & $\begin{array}{l}0.1 \% \mathrm{H}_{2} / 100 \\
0.1 \% \mathrm{H}_{2} / 100\end{array}$ & $\begin{array}{l}\text { Startup } \\
\text { Establish RR } \\
\text { Moisture } \\
\text { Cleanup } \\
\text { Calibration }\end{array}$ \\
\hline $\begin{array}{l}11-2 \\
11-3 \\
11-4 \\
11-5 \\
11-6 \\
11-7 \\
11-8 \\
11-9 \\
11-10 \\
11-11 \\
11-12 \\
11-13 \\
11-14 \\
11-15 \\
11-16\end{array}$ & $\begin{array}{l}100 \\
100 \\
100 \\
100 \\
100 \\
100 \\
100 \\
100 \\
100 \\
100 \\
100 \\
100 \\
100 \\
100 \\
100\end{array}$ & $\begin{array}{l}625 \\
625 \\
625 \\
625 \\
625 \\
625 \\
625 \\
625 \\
625 \\
550 \\
625 \\
500 \\
625 \\
450 \\
625\end{array}$ & $\begin{array}{l}0.1 \%_{2} / 200 \\
0.1 \mathrm{H}_{2} / 100 \\
0.1 \% \mathrm{H}_{2} / 100 \\
0.1 \mathrm{H}_{2} / 50 \\
0.1 \% \mathrm{H}_{2} / 100 \\
0.01 \mathrm{H}_{2} / 100 \\
0.1 \% \mathrm{H}_{2} / 100 \\
0.0 \% \mathrm{H}_{2} / 100 \\
0.1 \% \mathrm{H}_{2} / 100 \\
0.1 \% \mathrm{H}_{2} / 100 \\
0.1 \% \mathrm{H}_{2} / 100 \\
0.1 \% \mathrm{H}_{2} / 100 \\
0.1 \% \mathrm{H}_{2} / 100 \\
0.1 \mathrm{H}_{2} / 100 \\
0.1 \% \mathrm{H}_{2} / 100\end{array}$ & $\begin{array}{l}0.1 \% \mathrm{H}_{2} / 100 \\
0.1 \% \mathrm{H}_{2} / 800 \\
0.1 \% \mathrm{H}_{2} / 100 \\
0.1 \% \mathrm{H}_{2} / 50 \\
0.1 \% \mathrm{H}_{2} / 100 \\
0.1 \% \mathrm{H}_{2} / 100 \\
0.01 \% \mathrm{H}_{2} / 100 \\
0.1 \% \mathrm{H}_{2} / 100 \\
0.1 \% \mathrm{H}_{2} / 100 \\
0.1 \% \mathrm{H}_{2} / 100 \\
0.1 \% \mathrm{H}_{2} / 100 \\
0.1 \% \mathrm{H}_{2} / 100 \\
0.1 \% \mathrm{H}_{2} / 100 \\
0.1 \% \mathrm{H}_{2} / 100 \\
0.1 \% \mathrm{H}_{2} / 100\end{array}$ & \\
\hline & & & & & $\begin{array}{l}\text { Establish RR } \\
\text { Calibration }\end{array}$ \\
\hline
\end{tabular}

\subsection{TRITIUM SYSTEMS TEST ASSEMBLY INTERFACE}

The TSTA at Los Alamos National Laboratory is intended to demonstrate the safe and effective processing of tritium in fusion facilities. To this end, Dr. J. L. Anderson, TSTA project manager, has proposed (see Appendix IV) that tritium removed by the BEATRIX-II tritium removal system be transferred to TSTA instead of the original plans for burial as tritiated waste.

The proposal is to be considered by the Working Group in a meeting on February 1989. The proposal has merit in terms of the overall fuel cycle of a fusion facility, i.e. the demonstration of tritium production all the way from sweep gas recovery from a solid breeder blanket to processing of a usable DT fuel. With this combination of facilities, a model of the overall blanket tritium processing can be obtained. 


\subsection{PLANNED ACTIVITIES}

The planned activities for the Phase I (Cycle 11) test in calendar years 1989 and 1990 are shown in Table 10. Assembly of the fusion MOTA-2A will be completed in February 1989 and the vehicle shipped to FFTF. Installation of the MOTA I\&C system and the tritium handling system into FFTF will be occurring in January and February 1989. The checkout of these systems will occur in March and Apri1 1989. The checkout of the tritium handling system will include a test with tritium gas to confirm the response of the gas analysis and tritium removal systems. Irradiation of the fusion MOTA is scheduled to begin in April 1989.

TABLE 10. BEATRIX-II Phase I, Cycle 11, Planned Activities

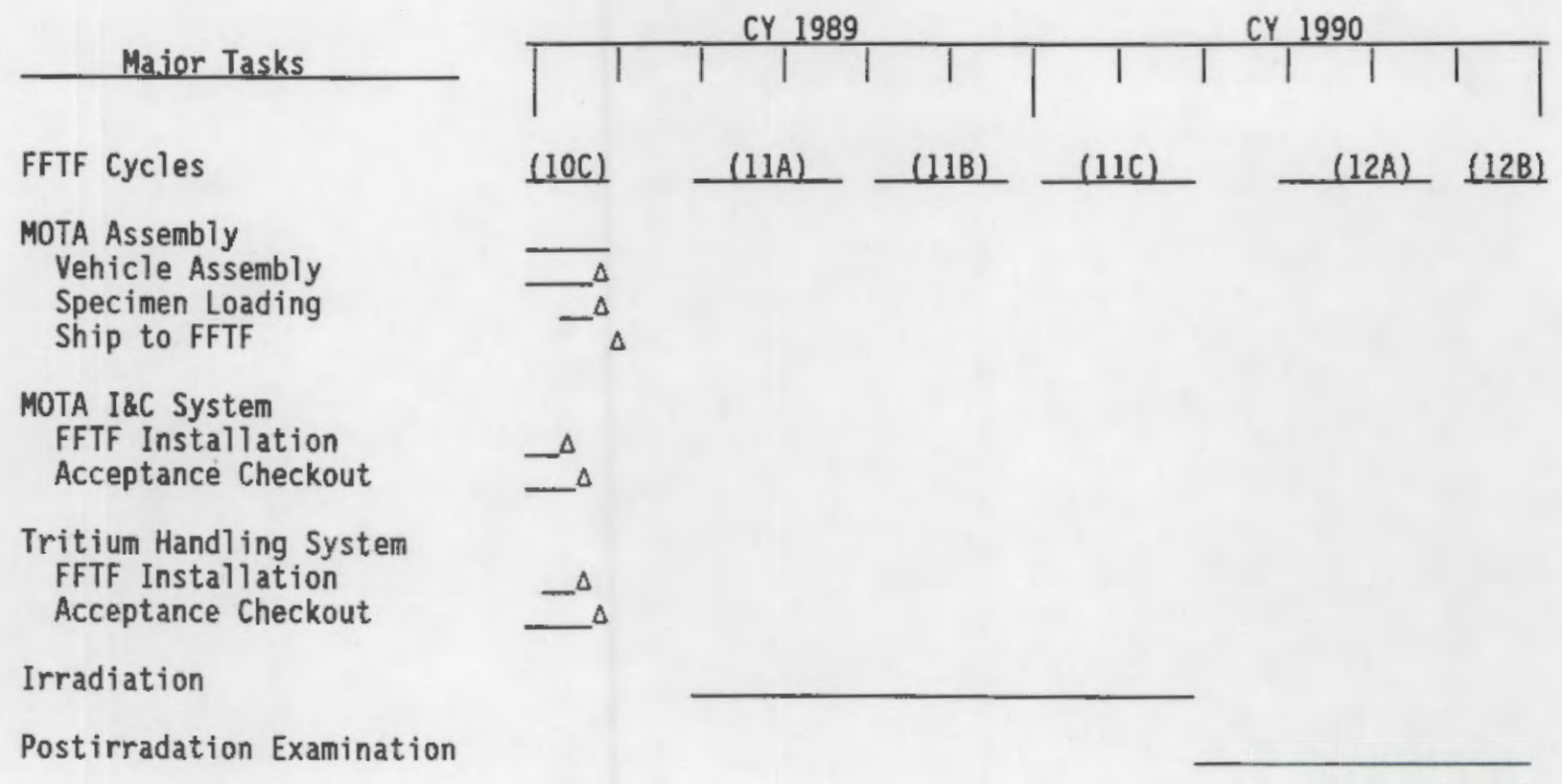





\subsection{PHASE II, CYCLE 12, PROPOSALS}

The scope and estimated cost of the BEATRIX-II, Phase II, Cycle 12 irradiation was not exactly defined in ANNEX-III. It is anticipated that the scope will be defined in a meeting of the BEATRIX-II Working Group on 13-14 February 1989. As in Cycle 11, IEA's partners (U.S. Fusion and Monbusho) are anticipating that $33 \%$ of the funding and available in-core space (10 canisters) will be associated with BEATRIX-II. 



\section{REFERENCES}

Letter to Distribution from T. C. Reuther (USDOE), 16 February 1988, Annex III Submission.

Letter to D. C. Corrigan from R. J. Puigh, 31 March 1987, "Technical Feasibility for the Solid Breeder Experiment in FFTF."

Letter to President, Westinghouse Hanford Co. from J. R. Hunter, Director Operations, April 19, 1988, "Approval-in-Principle for the Fusion Materials Open Test Assembly (MOTA)."

Letter to J. R. Hunter from R. W. Powell, 27 July 1987, "Request for Approval-in-Principle for the Fusion MOTA in FFTF."

Letter to Distribution from RL Goodman, 12 Apri1 1988, "Minutes and Action Items from IEA Final Design Review Meeting--March 8-9, 1988, In Richland, Washington."

Letter to Distribution from GW" Hollenberg, 15 Jan 1988, "BEATRIX-II Interim Design Review." 



\section{APPENDIX I}

ANNEX-III

FAST FLUX NEUTRON IRRADIATION OF CANDIDATE FUSION BREEDER BLANKET MATERIALS

(Subject to final approval of the Executive Committee) 
IEA Implementing Agreement on a Programme of Research and Development on Radiation Damage in Fusion Materials

ANNEX III January 29: 1988

\section{FAST FLUX NEUTRON IRRADIATION OF CANDIDATE FUSION BREEDER BLANKET MATERIALS}

\section{Backoround and Objective}

(a) Background. Following the successful pursuit of Breeder Exchange Matrix ("BEATRIX-I"), it is necessary to continue the collaborative effort to measure and evaluate the neutron irradiation effects, tritium release, and thermal properties of candidate fusion breeder blanket materiais in a high flux, fast neutron environment ("BEATRIXII"). The Fast Flux Test Facility ("FFTF") at Hanford, Washington, a multipurpose research reactor operated by the Westingnouse Hanford Company for the United States Department of Energy ("USOOE"), shall de used as the source for neutron $n$ irradiation of the candidate materials. In order to perform the planned experimental task, Materials Open Test Assemblies ("MoTAs") shall be specially designed, built, and operated as irradiation vehicles to be inserzed into FFTF.

(b) Objectives. The objectives of this Task are to collaborate in:

(i) The overall planning, design, fabrication, and assembly of the MOTA tritium system;

(ii) The formulation of the experimental matrix;

(iii) The fabrication, insertion, and irradiation of the MOTAs in FFTF;

(iv) The disassembly of the MOTAs;

(v) The postirradiation examination at FFTF and other sites; and

(vi) The reporting of results.

2. Means

(a) Programme. Cooperation between the Perticipants in this Annex (referred to in this Annex as the "Participants") in the activities to be conducted under this Annex shall include:

(i) The testing of candiaate solid breeder materials in a fast neutron environment, including temperature, time and burn-up variations, to study the effects of this environment on material behavior, chemical stability, in particular, tritium trapping and swelling;

(ii) The evaluation by continuous monitoring of the tritium release, thermal conductivity and temperature stability of these materials, up to hign burn-up levels of the litnium isotooes;

(iii) The evaluation of the compatioility oi tnese materials with the surrounding structures; and

(iv) This Task consists of the Phases I and II. Phase I is scineduled to oegin with Cycle 11 of FFTF in U.S. FY 1989 and 


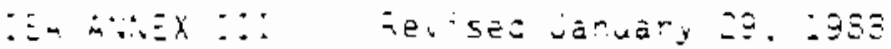

continue tinrough 2hase :I, FFT Cycle $i 2$ wrich is pianned to concluae in lis. Fy ig91. Scnecules for samole frevarazon and MOTA design and construction sriall be consistent witn Ene initiation of cycles 11 and $i 2$; schedules for postirradiation testing shall be consistent with the conclusion of those cycies. Subsequent testing may be consioered by the Participants.

(b) Working Group. The Participants shall establisin a Working Group to de composed of one representative aesignated by eacr Participants. In addition, each Particioant may have adoitional tecnnical advisers attend the meetings of the Working Group, including persons from appropriate facilities. The Working Group, which shall be convened by the Operating Agent at least annually or at intervals mutualiy agreed upon, shall report to the Executive Committee through the Operating Agent. Decisions of the Working Group shall be made by unanimity except that where unanimity is not achieved, each Participant's representative on the Working Group shall be entitled to have his views presented to the Executive Commiztee. The Horking Group will act as a steering committee for the conduct of the Task and wili be responsible for the preparation and supervision of the budget, schedule and scientific activities of the Task. The Horking Group shall develap and Program of Work and jugget wrich ine Particioanis shall review and recommend to their respective authorities and to the Executive Committee for approval. This Work Plan will cover tine fuil term of this Task supplemented annually with updated details of the budget, schedule, and scientific activities for the next twelve month period. The Program of Work and Budget shall also specify the contributions to provided by each participant. (c) Task Manaoer. The Operating Agent shall appoint a Task Manager who snali de responsible to the Operating Agent in coordination with the Working Group for the conduct of the work under this Task as specified in the Program of Work and Budget.

3. Resoonsibilities of the Particidants and the Working Groug

(a) Exchange of Information. Each Participant shali provide to the Operating Agent for transmission to the Working Group information dealing with neutron irradiation efiects, tritium reiease and thermal properties of candidate fusion breeder blanket materials in a high fiux, fast neutron environment. Based on such information, the Working Group shall review and adopt a common technical framework to be utiijzed in the work of each Participant undertaken pursuant to tinis Annex.

(b) Reference Materials. Each Participani shall provide to the Operating Agent for transmission to the Working Group information dealing with reference materials for neutron irradiation efiects, tritium reiease and thermal properties of candidate fusion breeder blanket materials in a high flux, fast neutron environment. Using this information the horking Group shali adopt reference materiais =0 provide a cominon basis for comparison of experimental resulis in these areas. 


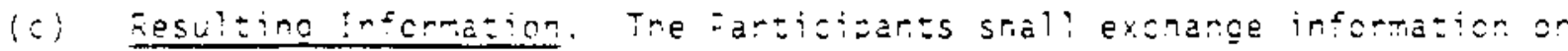
neitron irraciazion effeczs, trizium release arz tremini properzies of candidace fusion areeoer blanket materials in a nign fiux, fast neutron environment arising from tinis Task.

(d) Sumoosia. The Participancs shall arrange symposia when mutually agreed to discuss selected topics in neutron irradiation effects, tritium release and thermal properties of candidate fusion breeder bianket materials in a high flux, fast neutron environment.

(e) Assionment of Experts. The Participants shall assign experts in neutron irradiation effects, tritium release and thermal properties of candidate fusion breeder blanket materials to the Pacific Northwest Laboratories of USDOE (the site of FFTF), and if necessary, to other facilities of the Participants in accordance with agreements between the concerned Participants. The procedures to be followed in assigning experts shall be as follows:

(1) Each Participant desiring to assign an exoert shall through the Operating Agent submit its nomination to the farticipant in whose country the facility is located (tine Recipient Participant), as a rule, at least four months prior to the expected assignment date. Each such nomination shall specify the qualifications of the expert, nis werk during the assignment and the length of the assignment. The Recipient Participant shall, as soon as possible, notify the nominating Participant of the acceptability of the assignment. The nominating Participant and the Recipient Participant shail, in consultation with the Operating Agent, as required, attempt to reach agreement upon the specific terms applicable to such assignments, after which the assignments may be impiemented; except as may otherwise be agreed between the concerned Participants;

Publication resulting from theoretical or experimental investigation carried out in connection with this Annex and the assignment hereunder shall normally be issued in the form of joint redorts of the concerned Participants or individuals who contributed to the investigation;

(4) All personal expenses associated with an assignment, shall be borne by the assigning Participant. Such expenses shall include, but not be 1 imited to, costs of salary, cravel, insurance and living expenses of the assigned personnel. Assigned personnel shali in no way be deemed to be employees of the Recipient Participant by virtue of this assignment. Assigned personnel shall adhere to all safety and other operating procedures of the Recipient Participant;

(5) The Recipient Participant or its contractor shail provide ofifice space and relaced administrative support and facilities and access to laboratory space, shops, and equipment which are required to carry out the agreed assignment. The Recipien: Particioant will provide assistance anc acvice to assignees and their families in regard to nousing, cominumizj services, and general familiarization with the community; 


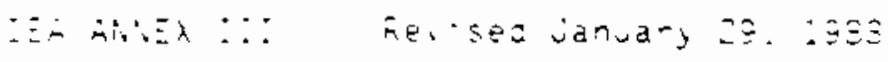

(E) Tne assigning farticizart agrees to inoemnify and ras ramiess che kecipient particisant, iss concraztor, and any persor acting on tneir oehalf for any camages, liabilities, or costs arising out of gross negligence or willful misconduct of personnel assigned under an agreement entered into in accordance with the provisions of this Annex; proviced, however, that this provision shall not apply to damages, liabilities, or costs insofar as and to the extent that they arise out of gross negligence or willful misconduct of the Recipient Participant, contractor, or persons acting on their behalf;

(7) Each expert on assignment may be accompanied by instrumentation or other such equipment necessary as part of his assignment to assist in data collection or diagnosis of experiments. The terms and conditions for transportation and use of such instrumentation and equipment shall be agreed upon in writing between the concerned Participants. USDOE shall confirm to L'S customs authorities that the equipment provided by Participants is of a scientific character and not of a commercial character. USDOE shall make its best effort to obtain tax-free clearance from US customs authorities for such equipment.

(f) Further Cooperation. The Woring Group shail, through the operating Agent, recommend to the Participants other joint cooperative efforts, including experiments. On the basis of such recommendations, the Participants shall decide upon further joint activities.

4. Specific Responsibilities of the Horking Group

in addition to the responsibilities mentioned above, the Working Group shall assist the Operating Agent in providing periodic technical reports and a final scientific reoort on the progress of work under this Annex to all Participants 25 well as supervising the preparation of the Program of Hork and Budget. A Chairman selected by the Working Group shall also attend the meetings of the Executive Committee. The lorking Group shall be responsible for the overall management of the work under the Annex.

\section{Information and Intellectual Prooerty}

(a) Executive Committee's Powers. The publication, distribution, handiing, protection and ownership of iniormation and intellectuat property arising from activities conducted under this Annex shall be determined by the Executive Committee, acting by unanimity, in conformity with this Agreement.

(b) Riaht to Publish. Subject only to the patents and copyright restrictions of this Annex, the Partizipants in this Annex shall have the right to publish all information provided to or arising from this Annex except proprietary information, but they shall not publish iz with a view to profit, except as agreed by the Executive Committee, acting by unanimity. Neither the Participants nor personnel cesignated by them shall introcuce into this iask any prosmistary 
information uniess susn information is soecificaily iaeritied anc sne terms ana conditions for its introcuztion are agreed uoon in writirg by the concerned Participants.

(c) Proorietary Information. The Participants shall take all necessary measures in accorcance with this Annex, the laws of their respective countries and international law to protect proprietary information. It is recognized that certain information made available to the Task may include industrial property of a proprietary nature. Such property, which may include trade secrets, inventions, patent information and "know-how", and which was acquired by a Participant prior to or outside the course of activities conducted under this Task shall be defined for the purposes of this Task as information which:

(1) Is of a type customarily held in confidence by commercial

firms:

(2) Is not generally known or publicly available from sources other than the Programme;

(3) Has not previously been made available to others by the Participant supplying it except under an agreement protecting its confidentiality; and

(4) Is not aiready in the possession of the recipient Participant or its contractor.

It shall be the responsibility of each Participant supplying proprietary infarmation to identify the information as such and to ensure that it is appropriately marked.

(d) Information. Each Participant agrees to provide to the other Participants and to the Operating Agent all information utilized in the activities under this Annex. All information developed in connection with and during activities carried out under this Annex (arising information) shall be provided to each Participant and to the Operating Agent by the Participant performing the work, subject only to the need to retain information concerning patentabie inventions in confidence until appropriate action can be taken to protect the rights to such inventions in accordance with paragraph (e) below. Reports containing arising information and pre-existing information necessary for and used in the activities under this Annex, including proprietary information in accordance with paragraphs (b) and (c) above, shail be provided to the Operating Agent and to the Participants by the Participant performing the work. The Operating Agent shali provioje summary reports of work performed under this Annex and arising information therefrom, otiner than proprietary information, if any, to the Executive Committee. In adoition, the Operating Agent shall provide management reports to all Participants on a quarterly basis and to the Executive Committee and the agency on an annual basis. The management reports shall include an accounting of task funds for the previous period. Information regarding inventions on which patent protection is to be obtained by the Participants shall not be published or publicly disclosed by the other Particioants or the Operating agent unil a patent application has been filed, provided, however, thit this restriction on bublicetion or disclesure siaili not extend beyond six montins from tne dace of receipt of such informazion. It shall be the responsibility of the inventing participant to 
aboropriazeiy mark recorts whisn distiose invarions ziaz rave rot

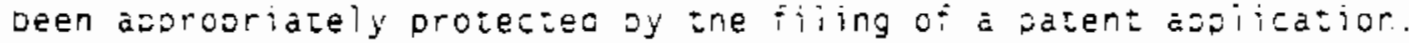

(e) Licensing of Inventions. With respect to any invention or discovery made or conceiveo in the course of or under this Annex:

(1) If made or conceiveo by personnel of one Participant (the Assigning Participant) or its contractors while assigned to the other Participant (Recipient Participant) or its contractors in connection with exchanges of scientists, engineers and otiner specialists:

(i) The Recipient Participant shall acquire all right, title and interest in and to ary such invention or discovery in its own country and ir third countries, subject to a non-exclusive, irrevocable, royalty-free license in all such countries to the Assigning Participant, and to its nationals designated by it;

(ij) The Assigning Participant shall acquire all right, title and interest in and to any such invention or discovery in its own country, subject to a non-exclusive, irrevocable, royalty-free license to the Recipient Participant, and to its nationals designated by it. If made or conceived during the course of or under this Annex by personnel of a Participant ozher trian in accordance with subparagraph (1), the Participant making the invention sinall acquire all right, title and interest in and to any such invention or aiscovery in all countries, provided however that the other Participants and its lationals desionaced by it shall be granced a non-exclusive, irravocable, royalty-free license in all other countries.

(f) Copvright. Each Participant may take appropriate measures necessary to protect copyrightable material generated unoer the Task.

Copyrights obtained shall be the property of that Participant, provided, however, that Participants may reproduce and distribute such material, but shall not pubi isn it with a view to profit.

(g) Inventors and Authors. Each Participant shall, without prejudice to any rigits of inventors or authors under its national laws, take all necessary steps to provide the cooperation from its authors and inventors required to carry out the provisions of this paragraph.Each Participant will assume the responsibility to pay awards or compensation required to be paid to its employees according to the laws of its country.

(h) Determination of "National". The Participants may establish guidelines to determine what constitutes a "national" of a Participant provided, however, in recognition of the fact that all fusion power research and develooment programmes of the individual Member States of the European Atomic Energy Community 'EURATOM) are carried out joirtly in the iramework of EURATOM, and that EURATOM acts on behalf of itseli and its iusion power ressarch and development associazed netional organizations in the EuRnTOl' Wemiver Stazes, and tnat Swiecen and Swizzeriand are associated with tine EURATOM Fusion Programme, the 


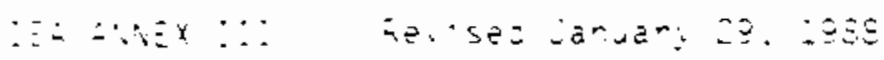

countries referred to in tnis saragrapn snail, with respect io

EJRATOM, Je unaerstood to de the countries of the Member Siaies of

EURATOM. Sweden and Swizzerland.

\section{Oserating Agent}

The Operating Agent for this Task shall be the United States Department of Energy. The Operating Agent shail perform all legal acts reouired to carry out the objectives of this Annex on behalf of the Participants, including tne recejpt, disbursement and accounting of funos and other concributions of the Participants required to perform the work of this Task. The Operating Agent shall prepare, verify, and distribute the minutes of the Working Group; shail assist personnel assignments as agreed by the Participants; and shall act as the central repository for all reports, publications and other informatian as collected and developed under this Annex, and shall be responsible for their distribution to al? Participants and Members of the Executive Commitree, and to others as directed by the Executive Committee. The cost for this administrative activity shall be funded from the Common Funds set forth in paragraph 7 below.

7. Funding

(2) A common fund shall be established for this Task by the Particioants. The annual amount of this fund shall be determined by the Paricicipants on the basis of the annual Program of Work and Budget deveioped by the Horking Group and approved by the Executive Comittee for the purpose of funding the obligations of the Operating Agent for this Task under Article 6(b) of the Agreement. The Operating Agent is not obligated to proceed without an approved Program of Work and Buoget and funding allocation.

(b) The Participants will jointly fund the expenditures incurred by the Operating Agent in fulfilling its responsibilities for Phase i (FFif Cycle \#ll) of this Task in accordance with the following Table oi Contributions:

Table of Contributions Planned for the IEA BEATRIX-II Phase I Experiment (thousand US dollars)

\begin{tabular}{|c|c|c|c|c|c|c|}
\hline Participant / & $\frac{\text { Period }}{[\text { [US FY] }}$ & 0 & $\frac{1}{[1988]}$ & $\frac{2}{1989]}$ & $\frac{3}{[1990]}$ & Total \\
\hline Canada & & 0 & $78+\star$ & (39) & 0 & $(117+*)$ \\
\hline Japan & & $400 * \star$ & 443 & $(318)$ & (91) & $(1252)$ \\
\hline United States & & 180 & 524 & $(327)$ & $(220)$ & $(: 251)$ \\
\hline TOTAL & & & & & & $(2620)+\dot{x}$ \\
\hline
\end{tabular}

loze: 1) The values srown in parenthes is are sucject to ene availability of appropriated funcs for each Participarit in iuture years. 
Note (Continued)

2) The asterisk ( $x$ ) indicates in-king contribution in che form of expertise and experience in the design, construction ano operation of experimental systems for tritium measurement and recovery.

3) The double asterisk $\left(^{\star \star}\right)$ indicates that the contribution shall be made before the end of March, 1988.

(c) The expenditure is not expected to exceed 2620000 US Doliars at lst January, 1988 price levels for the initial Phase (FFTF Cycle \#11) and may not exceed such level except upon the unanimous decision of the Participants. If significant changes in price levels or in the scope of activities under this Task occur, the Participants, acting by unanimity, shall decide whether to adjust the Program of Work and Budget to the availabie funds or to increase the budget;

(d) Contributions in kind or services may be accepted in lieu of cash. The value of any such contribution shall be fixed by the Participants, acting by unanimity, in the Executive Comittee;

(a) The contributions shall be made as provided in Articie 6(b) and (a) of the Agreement at such times and in such amouncs as shall be fixed by the Participants, acting by unanimity, in the Executive Commitzee.

8. Schedule

(a) This Annex shall enter into force on March 1, 1988, and shall remain in force for a period of five years subject to the effectiveness of the Agreement. It may be extended by agreement of two or more Participants acting in the Executive Commitiee. Extensions shall apply only to those Participants who agree to the extension and who notify the IEA Secretariat of their decision to continue to participate.

9. Particioation

(a) The Contracting Parties which are the nitial Participants in this Task are the following: Atomic Energy of Canada, Limited (AECL)

The Japan Atomic Energy Research Institute (JAERI)

The United States Department of Energy (USDOE) 


\section{APPENDIX II}

INTELLECTUAL PROPERTY OF BEATRIX-II PROGRAM 


\section{INTELLECTUAL PROPERTY OF BEATRIX-II PROGRAM}

A patent disclosure was drafted by Roger Bauer entitled "Thermal Conducting Porous Layer." It describes the channeled nickel layer that surrounds the solid pellet specimen which allows the sweep gas to flow around the specimen and still allows heat to be dissipated radially away from the pellets. 


\section{APPENDIX III}

DOCUMENTATION OF BEATRIX-II PROGRAM 
APPENDIX III

\section{DOCUMENTATION OF BEATRIX-II PROGRAM}

Two papers were presented on BEATRIX-II at international conferences with proceeding forthcoming:

1. "A Fast Neutron, In-Situ Tritium Recovery Experiment on Solid Breeder Materials," G. W. Hollenberg, T. Kurasawa, H. Watanabe, S. E. Berk, I. J. Hastings, J. Miller, D. E. Baker, R. E. Bauer, and R. J. Puigh, Eighth topical Meeting on the Technology of Fusion Energy, October 9-13, 1988, Salt Lake City, Utah.

2. "BEATRIX-II: In-Situ Tritium Recovery from a Fast Neutron Irradiation of Solid Breeder Materials," R. J. Puigh, G. W. Hollenberg, T. Kurasawa, H. Watanabe, I. J. Hastings, J. M. Miller, S. E. Berk, R. E. Bauer, and D. E. Baker, 15th Symposium on Fusion Technology, 19-23 Sept 1988, Utrecht, the Netherlands.

Design documents necessary for irradiation in FFTF are as follows:

1. WHC-SP-0255 "Test Design Description for the Fusion Materials Open Test Assembly (Fusion MOTA-2A) Specifications," Vol 18, Part 1 and 2, R. E. Bauer, November 1988, Westinghouse Hanford Co., Richland, WA.

2. WHC-SP-0224, "Test Design Description for the Fusion Materiais Open Test Assembly (Fusion MOTA-2A)," Parts I and 2, R. E. Bauer, November 1988, Westinghouse Hanford Co., Richland, WA. 


\section{APPENDIX IV}

ISTA PROCESSING OF BEATRIX-II TRITIUM 


\section{APPENDIX IV}

\section{TSTA PROCESSING OF BEATRIX-II TRITIUM}

Proposal by TSTA for processing of BEATRIX-II gettered tritium. 

LOS Alamos

Los Alamos National Laboratory

Los Alamos, New Mexico 87545
November 29, 1988

MST-3/TSTA-173-88

C348

(505) $667-1410$

(FTS) $843-1410$

Glenn W. Hollenberg

Battelle Pacific Northwest Laboratories

Battelle Boulevard

Richland, WA 99352

Dear Glenn:

I would like to propose that the BEATRIX II project consider the possibility that the tritium extracted from the solid breeder materials be sent to the Tritium Systems Test Assembly (TSTA) at Los Alamos for recovery. My understanding is that the extracted tritium will be collected in getter canisters with the intent of burying these canisters.

Since the getter material is regenerable it would be relatively straightforward for us to recover the tritium from these beds. We would need to know the history of the canisters, estimated quantities of hydrogen isotopes, including tritium, estimates of other species collected on the getter, and the total number of canisters to be used. We would then plan to regenerate the getters, collect the hydrogen isotopes, purify and separate the hydrogens using our plasma exhaust gas processing loop, thus demonstrating the applicability of the TSTA technology for this purpose. Based on our previous discussions, I estimate that the total quantity of tritium to be collected is about $7000 \mathrm{Ci}$. We would then use the tritium and canisters in our work at TSTA.

This recovery of tritium from the getter material would be done at no cost to BEATRIX II other than the cost of packaging and shipping the material to TSTA. I suspect that this cost would be no more than the cost of packaging the tritium contaminated getter for burial.

If there is interest in this proposal, I suggest that a meeting of key TSTA and BEATRIX II personnel could begin to work out the details on schedules, timing, and interfacing between BEATRIX II and TSTA. 
I look forward to your response to this proposal and the opportunity for possible collaboration between TSTA and BEATRIX II.

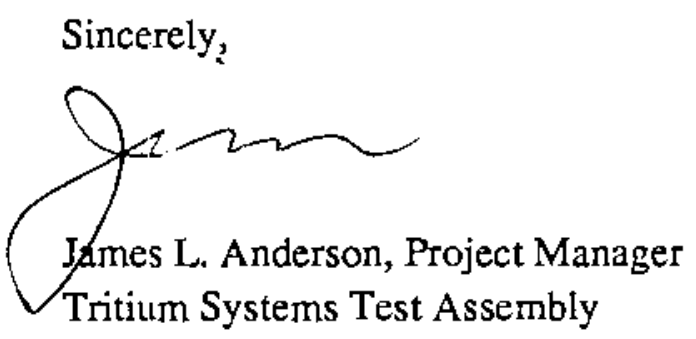

JLA/dv

Cy: G. Haas, DOE/OFE

G. Nardella, DOE/OFE

S. Berk, DOE/OFE

E. Walker, DOE/AL

R. Linford, ADET/MFE

G. Wewerka, MST-DO

K. Okuno, TSTA, MS C348

J. Bartlit, MST-3, MS C348

CRM-4 (2), MS A150

TSTA file 
PNL -6818

UC -423

\section{DISTRIBUTION}

No. of

Copies

\section{OFFSITE}

10 DOE/Office of Scientific and Technical Information

S. E. Berk ER-533, GTN

U.S. Department of Energy

Office of Fusion Energy

Washington, DC 20545

N. A. Davies

Chief, Tokamak System Branch

Division of Magnetic Fusion

Energy

U.S. Department of Energy

Washington, DC 20545

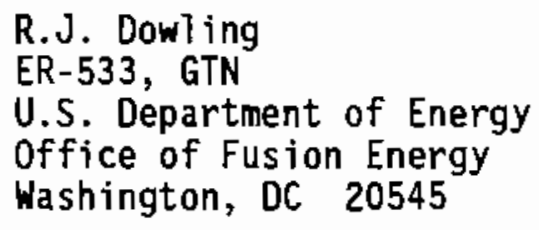

A. L. Opdenaker ER-533, GTN

U.S. Department of Energy Office of Fusion Energy

Washington, DC 20545

R. E. Price

ER-533, GTN

U.S. Department of Energy

Office of Fusion Energy

Washington, DC 20545

Dr. T. C. Reuther

ER-533, GTN

U.S. Department of Energy

Office of Fusion Energy

Washington, DC 20545
No. of

Copies

M. Roberts

Head, Project office

ER-521, GTN

U.S. Department of Energy

Office of Fusion Energy

Washington, DC 20545

J. Anderson

Los Alamos National Laboratory

P.0. Box 1663

Los ATamos, NM 97545

C. Baker

Los Alamos National Laboratory

P.0. Box 1663

Los Alamos, NM 97545

C. G. Bathke

Los Alamos National Laboratory

P.0. Box 1663

Mail Stop H82l

Los A7amos, NM 97545

M. Billone

Argonne Nationa] Laboratory

9700 South Cass Avenue

Building 205

Argonne, IL 60439

R. G. Clemmer

Argonne National Laboratory

9700 South Cass Avenue

Building 205

Argonne, IL 60439

Y. Gohar

Argonne Natjonal Laboratory

9700 South Cass Avenue

Building 205

Argonne, IL 60439 
No. of

Copies

C. E. Johnson

Argonne National Laboratory 9700 South Cass Avenue

Building 205

Argonne, IL 60439

D. L. Smith

Fusion Power Program, Bldg. 205

Argonne National Laboratory

g700 South Cass Avenue

Argonne, IL 60439

S. Piet

EG\&G

P.0. Box 1625

Idaho Falls, ID 83415

K. Schutz

General Atomic

P.0. Box 81608

San Diego, CA 92138

R. Moir

Lawrence Livermore National Labs

P.0. Box 5511 L-644

7000 East Avenue

Livermore, CA 94550

M. Abdou

School of Eng. \& Appl. Science

UCLA

Boelter Hall

$405 \mathrm{Hilgard}$ Avenue

Los Angeles, CA 90024

R. Raffray

School of Eng. \& Appl. Science

UCLA

Boelter Hill

$405 \mathrm{Hilgard}$ Avenue

Los Angeles, CA 90024
No. of

Copies

\section{FOREIGN}

Dr. R. E. Green

Atomic Energy of Canada Ltd.

Research Company

Chalk River Nuclear Lab

Chalk River, Ontario

CANADA KOJ 1 Jo

3 Dr. I. J. Hastings

Fuel Materials Branch

Atomic Energy of Canada Ltd.

Research Company

Chalk River Nuclear Lab

Chalk River, Ontario

CANADA KOJ 1 Jo

Dr. D. P. Jackson

Atomic Energy of Canada Ltd.

Research Company

Chalk River Nuclear Lab

Chalk River, Ontario

CANADA KOJ $1 \mathrm{JO}$

J. M. Miller

Atomic Energy of Canada Ltd.

Research Company

Chalk River Nuclear Lab

Chalk River, Ontario

CANADA KOJ $1 \mathrm{JO}$

Dr. E. 0. Moeck

Atomic Energy of Canada Ltd.

Research Company

Chalk River Nuclear Lab

Chalk River, Ontario

CAVADA KOJ $1 \mathrm{JO}$ 
No. of

Copies

Dr. G. J. Phillips

Manager, Fusion Fuels

Fusion Canada

Atomic Energy of Canada Ltd.

Research Company

Chalk River Nuclear Lab

Chalk River, Ontario

CANADA KOJ 1JO

Dr. H. K. Rae

Atomic Energy of Canada, Ltd.

Research Company

Chalk River Nuclear Lab

Chalk River, Ontario

CANADA KOJ IJO

Dr. D. P. Dautovich

Canadian Fusion Fuels

Technology Project

2700 Lakeshore Road West

MISSISSAUGA

Ontario L5J $1 \mathrm{~K} 3$

CANADA

Dr. P. Gierszewski

Canadian Fusion Fuels

Technology Project

2700 Lakeshore Road West

MISSISSAUGA

Ontario L5J 1K3

CANADA

Dr. K. Wong

Canadian Fusion Fuels

Technology Project

2700 Lakeshore Road West

MISSISSAUGA

Ontario L5J 1K3

CANADA
No. of

Copies

J. Darvas

DG XII - Fusion, SdM

200 , rue de la Loi

B 1040 Brussels

BELGIUM

Dr. R. Verbeek

Comission of European

Communities

Rue de La Loj 200

B-1040, Brusse]s,

BELGIUM

Dr. P. Von der Hardt

Commissione delle Comunita

Europee

Centro Comune di ricerca

Stabilimento di Ispra

21020 Ispra

Varese ITALY

T. Kondo

Deputy Director

Dept. of Fuels \& Materials Research

Japan Atomic Energy Research Institut

Tokai-mura Naka-gun

Ibaraki-ken 319-11 JAPAN

Dr. T. Kurasawa

Dept. of Fuels \& Materials Research

Japan Atomic Energy Research Institut

Tokai-mura Naka-gun

Ibaraki-ken 319-11

JAPAN 
No. of

Copies

Y. Naruse

Dept. of Fuels \& Materials Research

Japan Atomic Energy Research Institut

Tokaj-mura Naka-gun

Ibaraki-ken 319-11

JAPAN

5 Dr. H. Watanabe

Dept. of Fuels \& Materials Research

Japan Atomic Energy Research Inst itut

Tokaj-mura Naka-gun

Ibaraki-ken 319-11

JAPAN

Dr. M. Briec

Commissariat A L'energie Atomique

Institut De Recherche et de Develop Industrael

DESICP - CEN/Grenoba 1

Chemin - Des Martyrs

3800 Grenobal FRANCE

N. Roux

CEN/SACLAY

IRDI/DESICP/DPC/SPOM/SPCE

91191 FIG SUR YVETTE CEDEX

Saclay,

FRANCE

H. Kwast

Nether 1 ands

Energy Research Foundation EN

Materials Department

3 Hesterduinweg

P.0. Box I

1755 ZG Petten (NH)

THE NETHERLANDS
No. of

Copies

Dr. K. Kunmerer

Lejter des Instituts für

Materia1-und Festkörperforschung (IMF III)

Postfach 3640

7500 Karls sruhe 1

WEST GERMANY

\section{ONSITE}

3 DOE Richland Operations office

EC Norman

PM Pak

DL Sours, w/o attach.

8 Westinghouse Hanford Company

RE Bauer

KR Birney

HW Heacock

JJ Holmes

DJ Newland

RJ Puigh

RD Redekopp

HH Yoshikawa

18 Pacific Northwest Laboratory

TT Claudson

DG Doran

MD Freshley

GW Hollenberg (5)

$\mathrm{RH}$ Jones

BD Shipp

OD Slagle

UL Straalsund

Putlishing Coordination

Technical Report Files 